Check for updates

Cite this: RSC Adv., 2017, 7, 43798

Received 20th July 2017

Accepted 5th September 2017

DOI: $10.1039 / \mathrm{c} 7 \mathrm{ra0} 8010 \mathrm{~g}$

rsc.li/rsc-advances

\section{Synthesis and characterization of a $\mathrm{ZnMn}_{2} \mathrm{O}_{4}$ nanostructure as a chemical nanosensor: a facile and new approach for colorimetric determination of omeprazole and lansoprazole drugs}

\begin{abstract}
Mostafa Y. Nassar, (D) *a Eman A. El-Moety ${ }^{\mathrm{b}}$ and M. F. El-Shahat*c
We have developed a facile method for preparation of $\mathrm{ZnMn}_{2} \mathrm{O}_{4}$ nanostructures via an auto-combustion method using various fuels: urea, glycine and L-alanine. The type of fuel and $\mathrm{pH}$ of the combustion media have a significant effect on the combustion products. Glycine fuel generated spinel $\mathrm{ZnMn}_{2} \mathrm{O}_{4}$ on combustion, and calcination of the sample produced pure spinel $\mathrm{ZnMn}_{2} \mathrm{O}_{4}$ nanoparticles with an average crystallite size of $19 \mathrm{~nm}$. Whereas, other fuels generated multiphase compounds on combustion. The products were elucidated by means of XRD, FE-SEM, EDS, TEM, FT-IR, and UV-Vis diffuse reflectance spectra. The as-fabricated product was applied to construct a novel chemical nanosensor for the determination of omeprazole and lansoprazole drugs. Different factors influencing the colorimetric determination of the drugs were examined such as contact time, temperature, initial drug concentration, and $\mathrm{ZnMn}_{2} \mathrm{O}_{4}$ dose. The proposed chemical nanosensor revealed high sensitivity, low detection limit, and a relatively wide linear range $\left(0.80-8.0\right.$ and $0.80-8.8 \mu \mathrm{g} \mathrm{mL}^{-1}$ at $\lambda_{\max } 454 \mathrm{~nm}$ for omeprazole and lansoprazole, respectively).
\end{abstract}

\section{Introduction}

A growing interest in spinel metal oxide nanostructures; $\mathrm{AB}_{2} \mathrm{O}_{4}$ (A and $\mathrm{B}=$ metal), has been observed in the past few years. ${ }^{\mathbf{1 - 4}}$ This intensive interest is due to the unique physical and chemical properties that these oxides possess, which make them suitable for various applications. ${ }^{5-9}$ Among these spinel nanostructures, nano-sized zinc manganite $\left(\mathrm{ZnMn}_{2} \mathrm{O}_{4}\right)$ has received a considerable attention due to its various applications such as in sensors, electrodes, lithium rechargeable batteries, specific memory devices, thermistors, and catalysis. ${ }^{\mathbf{1 0}-\mathbf{1 4}}$ Therefore, many research groups have devoted their efforts to synthesizing spinel $\mathrm{ZnMn}_{2} \mathrm{O}_{4}$ nanostructures. In this light, $\mathrm{ZnMn}_{2} \mathrm{O}_{4}$ nanostructures with different morphologies and particle sizes have been prepared using various routes such as pyrolysis, solvothermal, electrospinning, hydrothermal, sol-gel, and the solid state method. ${ }^{\mathbf{1 5}-18}$ However, some of these techniques are time-consuming, relatively complicated and expensive, as well as they include sophisticated instruments. Searching for a facile, inexpensive, and less time-consuming process for the production of $\mathrm{ZnMn}_{2} \mathrm{O}_{4}$ nanostructures is still

${ }^{a}$ Chemistry Department, Faculty of Science, Benha University, Benha 13815, Egypt. E-mail: m_y_nassar@yahoo.com; m_y_nassar@fsc.bu.edu.eg; Tel: +20 1068727555 ${ }^{b}$ National Cancer Institute, Cairo, Egypt

${ }^{c}$ Chemistry Department, Faculty of Science, Ain Shams University, Cairo, Egypt. E-mail: elshahatmf@hotmail.com; Tel: +20 1128323115 a challenge. Besides, combustion process can fulfill these requirements since it is an inexpensive, simple, short timeconsuming, and scalable procedure. ${ }^{19-21}$ In addition, this method produces porous materials with high surface areas owing to the evolution of gasses during the combustion process. ${ }^{19-21}$ In this respect, reports on the synthesis of $\mathrm{ZnMn}_{2} \mathrm{O}_{4}$ nanostructures using combustion methods are still limited. ${ }^{2,23}$ However, the combustion processes were not extensively investigated in those reports. And the reported preparations applied higher temperatures, during the calcination steps, and produced nanoparticles with larger crystallite sizes in comparison to our current investigation, as will be explained later in the Results and discussion section.

On the other hand, lansoprazole; $\mathrm{C}_{16} \mathrm{H}_{14} \mathrm{~F}_{3} \mathrm{~N}_{3} \mathrm{O}_{2} \mathrm{~S}$, 2-[[[3methyl-4-(2,2,2-trifluoroethoxy)-2-pyridinyl]methyl]sulphinyl]$1 H$-benzimidazole, is a proton pump inhibitor, and it is effectively used for treatment of gastric ulcers and duodenal. ${ }^{24}$ This drug is a chemosensitizing cytotoxic, and it can treat various human tumor cells. ${ }^{25}$ In addition, omeprazole; $\mathrm{C}_{17} \mathrm{H}_{19} \mathrm{~N}_{3} \mathrm{O}_{3} \mathrm{~S}$, 6methoxy-2-[[(4-methoxy-3,5-dimethyl-2-pyridinyl)methyl]sulphinyl]- $1 H$-benzimidazole, is a proton pump inhibitor which can be used for treatment of symptomatic gastro-esophageal reflux, gastroduodenal ulcers, and Zollinger-Ellison syndrome. ${ }^{26,27}$ This drug can enhance the oral digoxin bioavailability by decreasing the acid production in the stomach and increasing the gastric permeability to digoxin. ${ }^{26}$ Some methods have been developed for quantitative determination of 
lansoprazole and omeprazole drugs in formulations and biological fluids such as HPLC, ${ }^{28,29}$ capillary electrophoresis, ${ }^{30,31}$ spectrophotometry, ${ }^{32}$ and voltammetry. ${ }^{33,34}$ However, the demand for a simple, reliable, and inexpensive analytical assay of the aforementioned drugs is growing due to their importance. Additionally, it is reported that organic sulfide compounds can be readily converted into sulfoxide $\left(\mathrm{R}_{2} \mathrm{SO}\right)$ and/ or sulfone $\left(\mathrm{R}_{2} \mathrm{SO}_{2}\right)$ compounds by oxidation. ${ }^{35,36}$

Based on the approach presented, we have herein developed a facile synthetic method for the preparation of $\mathrm{ZnMn}_{2} \mathrm{O}_{4}$ nanoparticles via an auto-combustion method. Therefore, we have investigated different parameters influencing the product species and their crystallite sizes such as fuel type and $\mathrm{pH}$ of the combustion media. Moreover, we have developed, for the first time, a simple, accurate, and sensitive colorimetric determination method for omeprazole and lansoprazole drugs in their pharmaceutical formulations based on the as-prepared $\mathrm{ZnMn}_{2} \mathrm{O}_{4}$ nanostructure as a chemical sensor.

\section{Experimental}

\subsection{Materials and reagents}

Zinc nitrate $\left(\mathrm{Zn}\left(\mathrm{NO}_{3}\right)_{2} \cdot 6 \mathrm{H}_{2} \mathrm{O}\right)$, manganese nitrate $\left(\mathrm{Mn}\left(\mathrm{NO}_{3}\right)_{2}{ }^{-}\right.$ $\left.\cdot 4 \mathrm{H}_{2} \mathrm{O}\right)$, potassium chloride $(\mathrm{KCl})$, L-alanine $\left(\mathrm{CH}_{3} \mathrm{CH}\left(\mathrm{NH}_{2}\right)\right.$ $\mathrm{COOH})$, glycine $\left(\mathrm{NH}_{2} \mathrm{CH}_{2} \mathrm{COOH}\right)$, urea $\left(\mathrm{NH}_{2} \mathrm{CONH}_{2}\right)$, were provided by Sigma-Aldrich Company. Nitric acid $\left(\mathrm{HNO}_{3}\right)$ was supplied by Carlo Erba Company, France. Ammonia solution $33 \%\left(\mathrm{NH}_{4} \mathrm{OH}\right)$ was purchased from El Nasr Pharmaceutical Chemicals Company (ADWIC) - Company, Egypt. Lansoprazole and omeprazole (Scheme 1) were kindly provided by El Arabeya Company for Pharmaceutical and Chemical Industries, Egypt. All other reagents and chemicals used, as received without any further purification, were of analytical grade.

\subsection{Fabrication of $\mathrm{ZnMn}_{2} \mathrm{O}_{4}$ nanostructures (chemo- sensors) using different fuels}

We have proposed an auto-combustion method to prepare $\mathrm{ZnMn}_{2} \mathrm{O}_{4}$ nanoparticles employing three different fuels: L-alanine, glycine and urea, and the as-prepared $\mathrm{ZnMn}_{2} \mathrm{O}_{4}$ products will be denoted as $\mathrm{A}, \mathrm{G}$, and $\mathrm{U}$, respectively. It is noteworthy that in the present combustion method, the stoichiometric compositions of the redox mixtures are calculated based on that the total reducing $(F)$ valency of the fuel and the total oxidizing $(O)$ valency of the mixed metal nitrate salts verify that $\Phi_{\mathrm{c}}=(F / O)=1$ (where, $\Phi_{\mathrm{c}}$ is the equivalence ratio). ${ }^{21,37}$ This was carried out to release the maximum quantity of heat from the combustion process. In a typical procedure: zinc nitrate ( $3.00 \mathrm{~g}, 10.08 \mathrm{mmol}, 1.00 \mathrm{eq}$.) and manganese nitrate $(5.06 \mathrm{~g}$, $20.02 \mathrm{mmol}, 2.00$ eq.) were dissolved in $40 \mathrm{~mL}$ bi-distilled water. Then, a glycine aqueous solution; $40 \mathrm{~mL},(2.52 \mathrm{~g}, 33.57 \mathrm{mmol}$, 3.33 eq.) was added to the stirring mixed zinc/manganese nitrate aqueous solution. The reaction blend $\mathrm{pH}$ was adjusted using ammonia solution $(1: 1)$ to $\mathrm{pH} 6$. The reaction blend was then stirred at $80{ }^{\circ} \mathrm{C}$ until it turned into a viscous liquid. After that, the temperature of the reaction mixture was increased to $300{ }^{\circ} \mathrm{C}$, while a vigorous self-propagating combustion reaction took place and lasted for $c a .5 \mathrm{~min}$. The as-burnt material $\left(\mathrm{G}_{6}\right)$ was ground then calcined at $500{ }^{\circ} \mathrm{C}$ for $2 \mathrm{~h}$ producing $\mathrm{ZnMn}_{2} \mathrm{O}_{4}$ products denoted as $\mathrm{G}_{6 \_500}$. This procedure was repeated using glycine fuel at different $\mathrm{pH}$ values such as 3 and 10 using nitric acid or ammonia solution $(1: 1)$, producing products labelled $\mathrm{G}_{3}$ and $\mathrm{G}_{10}$, respectively. Besides, we synthesized $\mathrm{ZnMn}_{2} \mathrm{O}_{4}$ products using similar combustion procedure and calcination temperature, while different fuels such as urea and $\mathrm{L}$-alanine were utilized and the corresponding products were labelled as $\mathrm{U}$ and $\mathrm{A}$, respectively. In addition, the aforementioned combustion and calcination steps were repeated while $\mathrm{pH}$ of the combustion media was adjusted at 3, 6 or 10 using nitric acid or ammonia solution, respectively. And the produced $\mathrm{ZnMn}_{2} \mathrm{O}_{4}$ products were referred to as $\mathrm{U}_{3}, \mathrm{U}_{6}, \mathrm{U}_{10}, \mathrm{~A}_{3}, \mathrm{~A}_{6}$ and $\mathrm{A}_{10}$, according to the corresponding fuel and $\mathrm{pH}$.

\subsection{Materials characterization}

The composition and phase purity of the as-fabricated products were analyzed utilizing powder X-ray diffraction (XRD) patterns measured by $18 \mathrm{~kW}$ diffractometer (Bruker; model D8 Advance) equipped with a monochromated $\mathrm{Cu}-\mathrm{K} \alpha$ radiation $(\lambda=1.54178$ $\AA)$. Morphologies of the as-fabricated $\mathrm{ZnMn}_{2} \mathrm{O}_{4}$ products were examined using a field emission scanning electron microscope (FE-SEM) connected with a microscope (FE-SEM) (JEOL JSM$6500 \mathrm{~F}$ ). And TEM images of the as-fabricated $\mathrm{ZnMn}_{2} \mathrm{O}_{4}$ products were taken using a high-resolution transmission electron microscope (HR-TEM) (JEM-2100) at $200 \mathrm{kV}$ accelerating voltage. The functional groups of the as-fabricated $\mathrm{ZnMn}_{2} \mathrm{O}_{4}$ products were determined by collecting their FT-IR spectra in the range of $4000-400 \mathrm{~cm}^{-1}$ employing an FT-IR spectrometer

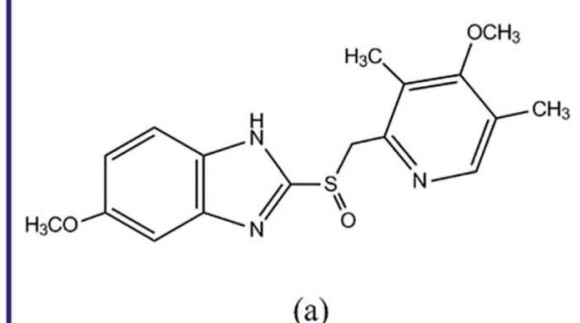

(a)

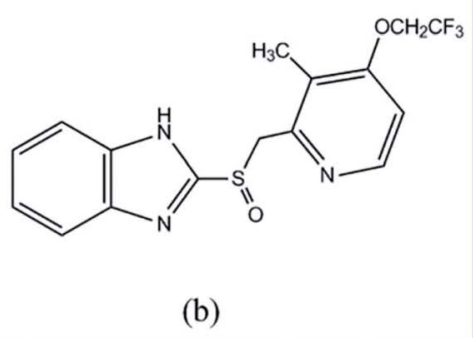

(b)

Scheme 1 Chemical structures of omeprazole (a) and lansoprazole (b) drugs. 


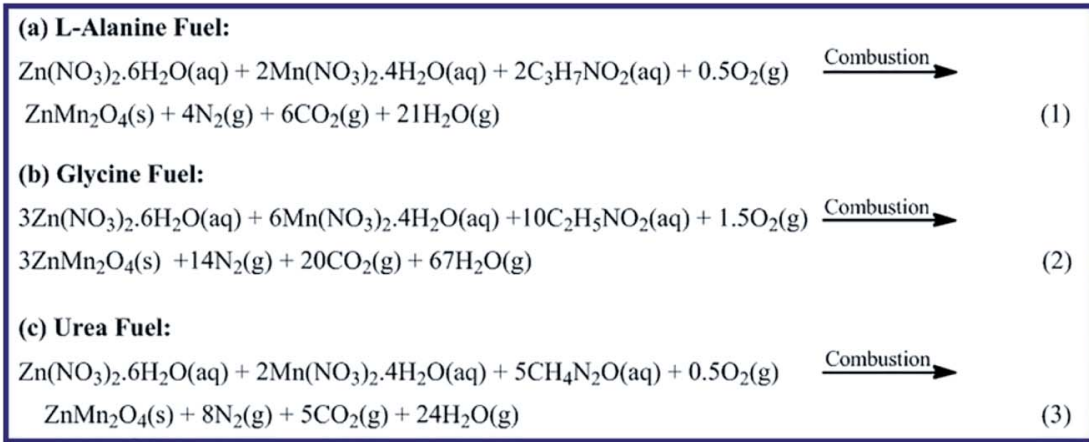

Scheme 2 The proposed combustion reactions of zinc and manganese nitrates with L-alanine, glycine, and urea fuels.

(Thermo Scientific; model Nicolet iS10) utilizing $\mathrm{KBr}$ pellets. The UV-Visible spectra of the drug solutions, under investigation, were measured on an UV-Vis spectrophotometer (Jasco, model v670).

\subsection{Colorimetric determination of lansoprazole and omeprazole drugs}

For the determination of lansoprazole and omeprazole drugs with an initial concentration of $10 \mathrm{mg} \mathrm{L}^{-1}$ (dissolved in ethanol), $0.05 \mathrm{~g}$ of the as-prepared $\mathrm{ZnMn}_{2} \mathrm{O}_{4}$ chemosensor was added to $20 \mathrm{~mL}$ of the prepared drug solution, and the $\mathrm{pH}$ value of the solution was adjusted using $0.5 \mathrm{M} \mathrm{HNO}_{3}$ or $\mathrm{NaOH}$ solutions. After that, the volume of the reaction mixture was adjusted to $25 \mathrm{~mL}$ by the addition of bi-distilled water, and the mixture was then allowed to stir for a specific time. Notably, the color of the drug solution after addition of the chemosensor nanomaterial turned into yellow. Different parameters influencing the developing of that yellow color have been investigated such as contact time, $\mathrm{pH}, \mathrm{ZnMn}_{2} \mathrm{O}_{4}$ dose, initial drug concentration, and temperature. The absorbance spectra of the supernatant were measured employing an UV-Vis spectrophotometer at $\lambda_{\max }=454 \mathrm{~nm}$, after separation of the suspension by centrifugation. Interestingly, the order of addition does not influence the accuracy, sensitivity, and reproducibility of the present developed method.

\section{Results and discussion}

\subsection{Auto-combustion fabrication and characterization of $\mathrm{ZnMn}_{2} \mathrm{O}_{4}$ chemosensor}

In our earlier study, we have reported on the preparation of $\mathrm{MgAl}_{2} \mathrm{O}_{4}, \mathrm{MgO}$, and $\mathrm{TiO}_{2}$ nanostructures via a combustion procedure using metal nitrate salts and different fuels. ${ }^{19-21}$ And we concluded that the fuel type and equivalence ratio $\left(\Phi_{\mathrm{c}}\right)$ value influenced the crystallite sizes of the products. However, we have not examined the effect of $\mathrm{pH}$ of the combustion media on the combustion process. Therefore, in this light, we have explored the influence of fuel type and combustion media $\mathrm{pH}$ on the combustion of zinc/manganese nitrate (oxidant). As we will explain later, the type and amount of the fuel, as well as the $\mathrm{pH}$ value of the combustion media have a significant impact on the combustion products, their morphologies, and their crystal sizes. Hence, the combustion reactions between zinc nitrate/ manganese nitrate and a fuel such as glycine, L-alanine, or urea, were carried out at different $\mathrm{pH}$ values and at fuel-tooxidant equivalence ratio $\left(\Phi_{c}\right)$ of 1 . The produced $\mathrm{ZnMn}_{2} \mathrm{O}_{4}$ nanostructure obtained at the optimum conditions was then applied to colorimetric determination of omeprazole and lansoprazole drugs. The proposed combustion reactions are presented in Scheme 2. The combustion and calcined products were analyzed using XRD, FR-IR, SEM, UV-Vis reflectance, and TEM techniques.

3.1.1. XRD study. The crystal structures of the combustion products were investigated using the X-ray diffraction technique. Fig. 1 through 3 present the XRD patterns of the combustion and calcined products using $\mathrm{L}$-alanine, glycine, and urea fuels at different $\mathrm{pH}$ values $(3,6$, and 10$)$ at $\Phi_{\mathrm{c}}=1$. Inspection of the figures revealed that the fuel type and $\mathrm{pH}$ of the combustion media have a significant impact on the phase composition and crystallite size of the products. It is reported that $\mathrm{pH}$ of the starting solutions of the combustion media can prevent selective precipitation and/or phase segregation during.

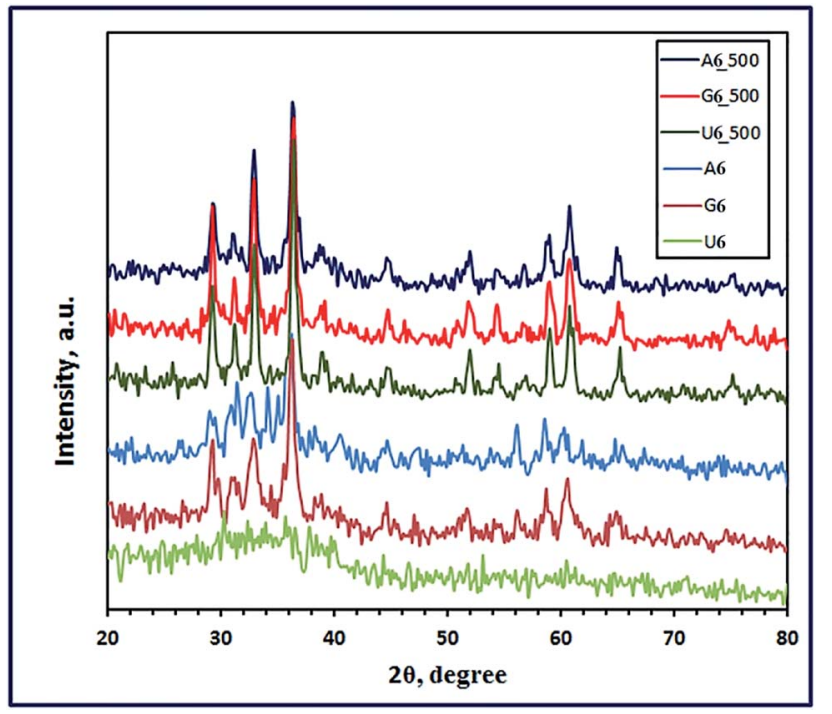

Fig. 1 XRD patterns of the as-fabricated $\mathrm{ZnMn}_{2} \mathrm{O}_{4}$ products after combustion $\left(A_{6}, G_{6}\right.$, and $\left.U_{6}\right)$ and calcination $\left(A_{6 \_500}, G_{6 \_500}\right.$, and $\left.\mathrm{U}_{6 \_500}\right)$ using L-alanine, glycine and urea fuels, respectively. 


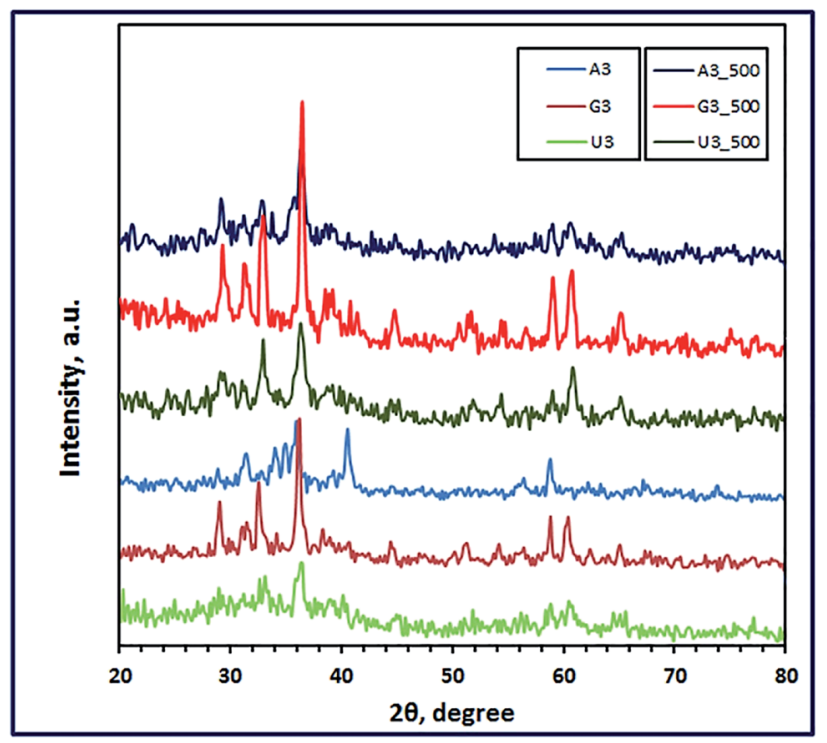

Fig. 2 XRD patterns of the as-fabricated $\mathrm{ZnMn}_{2} \mathrm{O}_{4}$ products (at $\mathrm{pH}$ 3) after combustion $\left(A_{3}, G_{3}\right.$, and $\left.U_{3}\right)$ and calcination $\left(A_{3} 500, G_{3} 500\right.$, and $\left.U_{3 \_500}\right)$ using $L$-alanine, glycine and urea fuels, respectively.

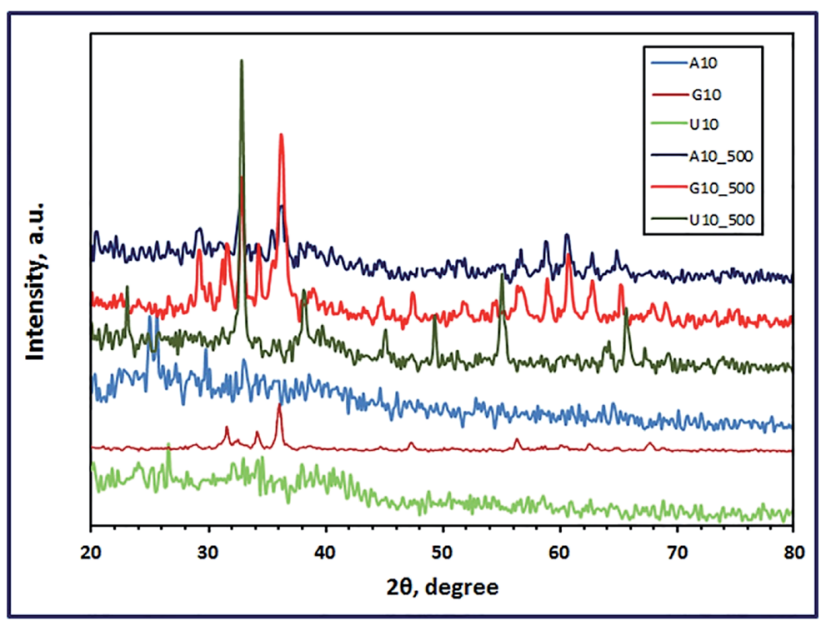

Fig. 3 XRD patterns of the as-fabricated $\mathrm{ZnMn}_{2} \mathrm{O}_{4}$ products (at $\mathrm{pH}$ 10) after combustion $\left(A_{10}, G_{10}\right.$, and $\left.U_{10}\right)$ and calcination $\left(A_{10} 500, G_{10} 500\right.$, and $U_{10 \_500}$ ) using L-alanine, glycine and urea fuels, respectively.

the combustion process which may cause phase inhomogeneity of the reaction blend. ${ }^{38}$ In the current investigation, we used different fuels such as urea, L-alanine, and glycine, which might act simultaneously as chelating agents as well. The formation of metal coordination or metal chelation complexes is a $\mathrm{pH}$ dependent. And the produced soluble chelation complexes are an essential point in preventing the selective precipitation of the cations of interest and this can support the homogeneity of the reaction media during solvents evaporation throughout the combustion process. ${ }^{38,39}$ Moreover, hydrolysis of the cation compounds and their complexes can be controlled by the $\mathrm{pH}$ value of the reaction media. ${ }^{40}$ Therefore, during the combustion process, there will be a competition between two main reactions: (1) formation of metal chelations and (2) hydrolysis of the formed metal chelations and other metal compounds. And these two main mechanisms can tune the phase, morphology, and/or crystallite size of the products of the combustion process. Based on this discussion, we can explain our following results. Fig. 1 revealed that $\mathrm{L}$-alanine fuel resulted in a mixture $\left(\mathrm{A}_{6}\right)$ of $\mathrm{ZnMnO}_{3}, \mathrm{ZnO}$, and $\mathrm{Mn}_{3} \mathrm{O}_{4}$ through the combustion process at $\mathrm{pH}$ 6. Calcination of this mixture at $500{ }^{\circ} \mathrm{C}$ for $2 \mathrm{~h}$ produced pure product $\left(\mathrm{A}_{6 \_500}\right)$, corresponding to tetragonal $\mathrm{ZnMn}_{2} \mathrm{O}_{4}$ (JCPDS card no. 24-1133, space group: $I 4_{1} / a m d$ ). The diffraction peaks of the $\mathrm{ZnMn}_{2} \mathrm{O}_{4}$ product appeared at $2 \theta$ values of $c a .29 .32^{\circ}, 31.23^{\circ}, 33.00^{\circ}, 36.41^{\circ}, 44.63^{\circ}, 58.92^{\circ}, 60.82^{\circ}$ and $64.82^{\circ}$ corresponding to the reflection planes values of (112), (200), (103), (211), (220), (321), (224), and (400), respectively. Fig. 2 and 3 revealed that combustion at $\mathrm{pH}$ value of 3 and 10 brought about a mixture of $\mathrm{ZnMn}_{2} \mathrm{O}_{4}, \mathrm{ZnO}$, and $\mathrm{MnO}\left(\mathrm{A}_{3}\right)$, and a mixture of $\mathrm{Zn}(\mathrm{OH})\left(\mathrm{NO}_{3}\right)\left(\mathrm{H}_{2} \mathrm{O}\right)$ and $\left(\mathrm{Mn}_{2} \mathrm{Zn}\right)_{7}(\mathrm{OH})_{10}\left(\mathrm{CO}_{3}\right)_{2}$ $\mathrm{Zn}_{5}(\mathrm{OH})_{8}\left(\mathrm{~A}_{10}\right)$, respectively. And calcination of the combustion products did not give a pure $\mathrm{ZnMn}_{2} \mathrm{O}_{4}$ product, but it resulted in different mixed oxides $\left(\mathrm{A}_{3 \_500}\right.$ and $\left.\mathrm{A}_{10 \_500}\right)$, as shown in Fig. 2 and 3. L-Alanine is an amino acid which can exist in three forms: ${ }^{+} \mathrm{NH}_{3} \mathrm{CH}\left(\mathrm{CH}_{3}\right) \mathrm{COOH},{ }^{+} \mathrm{NH}_{3} \mathrm{CH}\left(\mathrm{CH}_{3}\right) \mathrm{COO}^{-}$(zwitterionic form), and $\mathrm{NH}_{2} \mathrm{CH}\left(\mathrm{CH}_{3}\right) \mathrm{COO}^{-}$, as dominant species. This will depend on the $\mathrm{pH}$ values of the media: 3,6 , and 10 , since the isoelectric point value of this amino acid is 6 . The rate of formation of L-alanine-metal complexes is low at acidic $\mathrm{pH}$ values, and it enhances with increasing the $\mathrm{pH}$ value of the media. Besides, in alkaline media the formed chelate complexes may undergo hydrolysis forming hydroxide species, and this may result in formation of a mixture of different metal oxide species on combustion, as shown in Fig. 3.

Interestingly, the combustion reaction using glycine fuel at pH 6 and 3 gave pure tetragonal $\mathrm{ZnMn}_{2} \mathrm{O}_{4}$ (JCPDS card no. 241133, space group: $\left.I 4_{1} / \mathrm{amd}\right)$ with crystallite size values of $11\left(\mathrm{G}_{6}\right)$ and $27 \mathrm{~nm}\left(\mathrm{G}_{3}\right)$, respectively, as shown in Fig. 1 and 2. No other peaks were observed for other crystalline products in the XRD patterns. In addition, calcination of these combustion products gave $\mathrm{ZnMn}_{2} \mathrm{O}_{4}\left(\mathrm{G}_{6 \_500}\right)$ with crystallite size of $19 \mathrm{~nm}$, and a mixture of $\mathrm{ZnMn}_{2} \mathrm{O}_{4}, \mathrm{Mn}_{3} \mathrm{O}_{4}$, and $\mathrm{Mn}_{5} \mathrm{O}_{8}\left(\mathrm{G}_{3_{-5} 500}\right)$, as depicted in Fig. 1 and 2, respectively. Glycine is also an amino acid prevailing specific glycine species, based on $\mathrm{pH}$ values of the starting solutions of the combustion media. At $\mathrm{pH} 3$, glycine may exist mainly as ${ }^{+} \mathrm{NH}_{3} \mathrm{CH}_{2} \mathrm{COOH}$ and the coordination ability of this species with zinc and manganese cations is weak; moreover, glycine may exist mainly as ${ }^{+} \mathrm{NH}_{3} \mathrm{CH}_{2} \mathrm{COO}^{-}$(zwitterion, isoelectric point is $\sim 6$ ) at $\mathrm{pH} 6$ and the complexing ability of this ion is higher than the previous one. ${ }^{41}$ However, both $\mathrm{pH}$ values resulted in pure $\mathrm{ZnMn}_{2} \mathrm{O}_{4}$ nanostructures on combustion. The crystallite size of the burnt nanoparticles at pH 6 was smaller than that at $\mathrm{pH}$ 3. This may be attributed to that zwitterionic glycine-metal complexes are less soluble at $\mathrm{pH}$ 6 . And the formed nucleates may prefer to coagulate forming gel quickly during the evaporation of the solvent in the combustion process. Therefore, the primary small particles (crystallites) do not have much time in the combustion process to grow into larger crystallites producing smaller crystallites. ${ }^{40}$ Increasing the $\mathrm{pH}$ of the combustion to 10 enhanced the chelation ability of the glycine species at that $\mathrm{pH}\left(\mathrm{NH}_{2} \mathrm{CH}_{2} \mathrm{COO}^{-}\right)$; however, the 
rate of hydrolysis also increased forming different metal hydroxide species as precipitate along with various glycinemetal chelates. And this might explain producing of a mixture of different manganese-zinc oxides on combustion at $\mathrm{pH} 10$.

On the other hand, using urea as a fuel produced a mixture of $\mathrm{ZnMnO}_{3}$ and $\mathrm{Mn}_{3} \mathrm{O}_{4}$, or a mixture of $\mathrm{ZnMn}_{2} \mathrm{O}_{4}$ and $\mathrm{Mn}_{3} \mathrm{O}_{4}$ at pH $6\left(\mathrm{U}_{6}\right)$ or at pH $3\left(\mathrm{U}_{3}\right)$, respectively. Calcination of these combustion products at $500{ }^{\circ} \mathrm{C}$ for $2 \mathrm{~h}$ produced pure tetragonal $\mathrm{ZnMn}_{2} \mathrm{O}_{4}\left(\mathrm{U}_{6 \_500}\right.$ and $\left.\mathrm{U}_{3 \_500}\right)$ (JCPDS card no. 24-1133, space group: $I 4_{1} /$ amd ) with a crystallite size of 25 and $20 \mathrm{~nm}$, respectively, as shown in Fig. 1 and 2. We have not observed any other peaks for other crystalline products in the XRD patterns. Moreover, adjusting the $\mathrm{pH}$ of the combustion media to 10 gave $\left(\mathrm{Mn}_{2} \mathrm{Zn}\right)_{7}(\mathrm{OH})_{10}\left(\mathrm{CO}_{3}\right)_{2}$ precursor $\left(\mathrm{U}_{10}\right)$ on combustion, as shown in Fig. 3. However, calcination of that precursor produced a mixture of $\mathrm{ZnMn}_{2} \mathrm{O}_{4}$ and $\mathrm{Mn}_{2} \mathrm{O}_{3}\left(\mathrm{U}_{10}{ }_{500}\right)$. The obtained results exhibited that these $\mathrm{pH}$ values do not have a remarkable influence on the combustion products. This may be attributed to that during heating the solutions prior to the combustion process, urea decomposes into ammonia and $\mathrm{CO}_{2}$ which can increase the alkalinity of the media enhancing hydrolysis of the cations into different hydroxides. ${ }^{8}$ These metal hydroxides might be converted into various metal oxides on combustion. However, on sintering the burnt oxides, produced at $\mathrm{pH} 3$ and 6 , may react in the solid state forming pure $\mathrm{ZnMn}_{2} \mathrm{O}_{4}$ nanostructures.

Based on the obtained results, we have arrived at a conclusion that pure $\mathrm{ZnMn}_{2} \mathrm{O}_{4}$ nanoparticles can be synthesized using L-alanine and urea fuels at $\mathrm{pH} 6$ on combustion followed by calcination at $500{ }^{\circ} \mathrm{C}$ for $2 \mathrm{~h}$. However, the combustion process resulted in directly pure $\mathrm{ZnMn}_{2} \mathrm{O}_{4}$ nanoparticles when glycine fuel was used and the combustion media $\mathrm{pH}$ was 6 . And calcination of the combustion product in this case did not influence the product composition but it increased the crystallite size only. On the other side, adjusting $\mathrm{pH}$ to 3 produced pure $\mathrm{ZnMn}_{2} \mathrm{O}_{4}$ product only after calcination of the combustion products at $500{ }^{\circ} \mathrm{C}$ for $2 \mathrm{~h}$ when glycine and urea were used as fuels. Consequently, the present combustion method, in which $\Phi_{\mathrm{c}}=1$, gave pure spinel $\mathrm{ZnMn}_{2} \mathrm{O}_{4}$ nanoparticles with much smaller crystallite size compared to the reported one. ${ }^{22}$ In that reported method, the applied $\Phi_{\mathrm{c}}$ was not equal to 1 ; therefore, the authors used higher calcination temperature, $600{ }^{\circ} \mathrm{C}$, for a longer time $(6 \mathrm{~h})$ so that the produced crystallite size was $c a$. $50 \mathrm{~nm} .{ }^{22}$ Notably, the average crystallite sizes of the combustion and calcined pure products were estimated employing the Debye-Scherrer equation (eqn (4)) and listed in Table $1{ }^{42}$

$$
D=0.9 \lambda / \beta \cos \theta_{\mathrm{B}}
$$

where, $\beta, \lambda$, and $\theta_{\mathrm{B}}$ are the full width of the diffraction peak at half maximum (FWHM), X-ray radiation wavelength (nm), and Bragg diffraction angle, respectively.

3.1.2. FT-IR study. The chemical compositions of the combustion and calcination products were elucidated by using the FT-IR spectra. In this light, Fig. 4 revealed the FT-IR spectra of the combustion products generated using L-alanine, glycine, and urea fuels at fuel-to-oxidant equivalence ratio $\left(\Phi_{\mathrm{c}}\right)$ of 1 and at different $\mathrm{pH}$ values of the combustion media. The FT-IR results exhibited that glycine fuel was the optimum fuel for the current combustion procedure because this fuel generated $\mathrm{ZnMn}_{2} \mathrm{O}_{4}$ phase on combustion, at pH $3\left(\mathrm{G}_{3}\right)$ and $\mathrm{pH} 6\left(\mathrm{G}_{6}\right)$ of the combustion media (Fig. 4). This conclusion is based on the two characteristic vibrational frequencies appeared at ca. 496 and $615 \mathrm{~cm}^{-1}$ which can be attributed to $\mathrm{ZnMn}_{2} \mathrm{O}_{4} \cdot{ }^{43}$ However, this fuel at the aforementioned $\mathrm{pH}$ conditions produced some organic residue, and this was attributed to appearance of some vibrational frequencies at $c a .1050$ (C-O stretching) and $1426 \mathrm{~cm}^{-1}\left(\mathrm{CH}_{2}\right.$ stretching). This is consistent with the published results. ${ }^{\mathbf{4 3 , 4 4}}$ Notably, increasing the $\mathrm{pH}$ of the combustion media to $\mathrm{pH} 10$, resulted in different phases $\left(\mathrm{G}_{10}\right)$ on combustion as shown in Table 2. Nevertheless, the other used fuels (urea and alanine) did not gave pure $\mathrm{ZnMn}_{2} \mathrm{O}_{4}$ phase on combustion, as shown in Fig. 4 and Table 2. However, alanine fuel produced phases $\left(\mathrm{A}_{3}\right): \mathrm{ZnMn}_{2} \mathrm{O}_{4}, \mathrm{ZnO}$, and $\mathrm{MnO}$ (at $\mathrm{pH} 3$, $\mathrm{A}_{3}$ ), phases $\left(\mathrm{A}_{6}\right)$ : $\mathrm{ZnMnO}_{3}, \mathrm{ZnO}$, and $\mathrm{Mn}_{3} \mathrm{O}_{4}$ (at $\mathrm{pH}$ 6), and phases $\left(\mathrm{A}_{10}\right): \mathrm{Zn}(\mathrm{OH})\left(\mathrm{NO}_{3}\right)\left(\mathrm{H}_{2} \mathrm{O}\right)$ and $\left(\mathrm{Mn}_{2} \mathrm{Zn}\right)_{7}(\mathrm{OH})_{10}\left(\mathrm{CO}_{3}\right)_{2}$ $\mathrm{Zn}_{5}(\mathrm{OH})_{8}$ (at pH 10), along with some organic residues, ${ }^{2,43-49}$ as shown in Fig. 4 and Table 2. Urea fuel gave also different phases $\left(\mathrm{U}_{3}, \mathrm{U}_{6}, \mathrm{U}_{10}\right)$ on combustion at different $\mathrm{pH}$ values. Based on glycine fuel results, we focused on the combustion products $\left(\mathrm{A}_{6}\right.$, $\mathrm{G}_{6}, \mathrm{U}_{6}$ ) generated using the three fuels at $\mathrm{pH} 6$, for comparison purpose. These combustion products were calcinated at $500{ }^{\circ} \mathrm{C}$

Table 1 Influence of fuel, $\mathrm{pH}$ and calcination temperature on the produced phases of the combustion processes

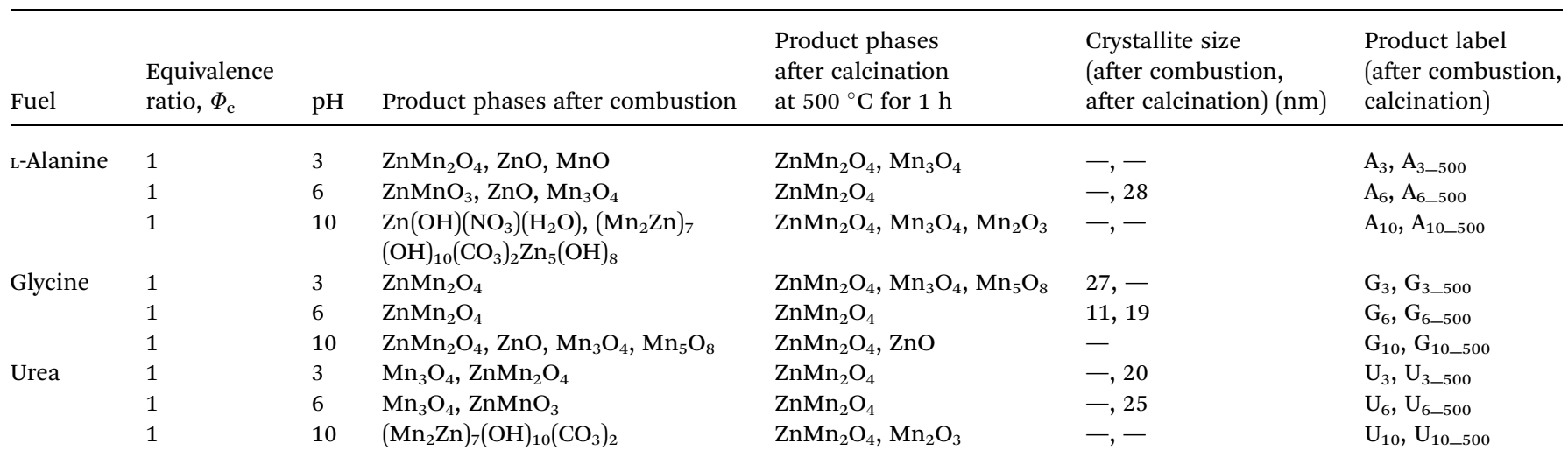




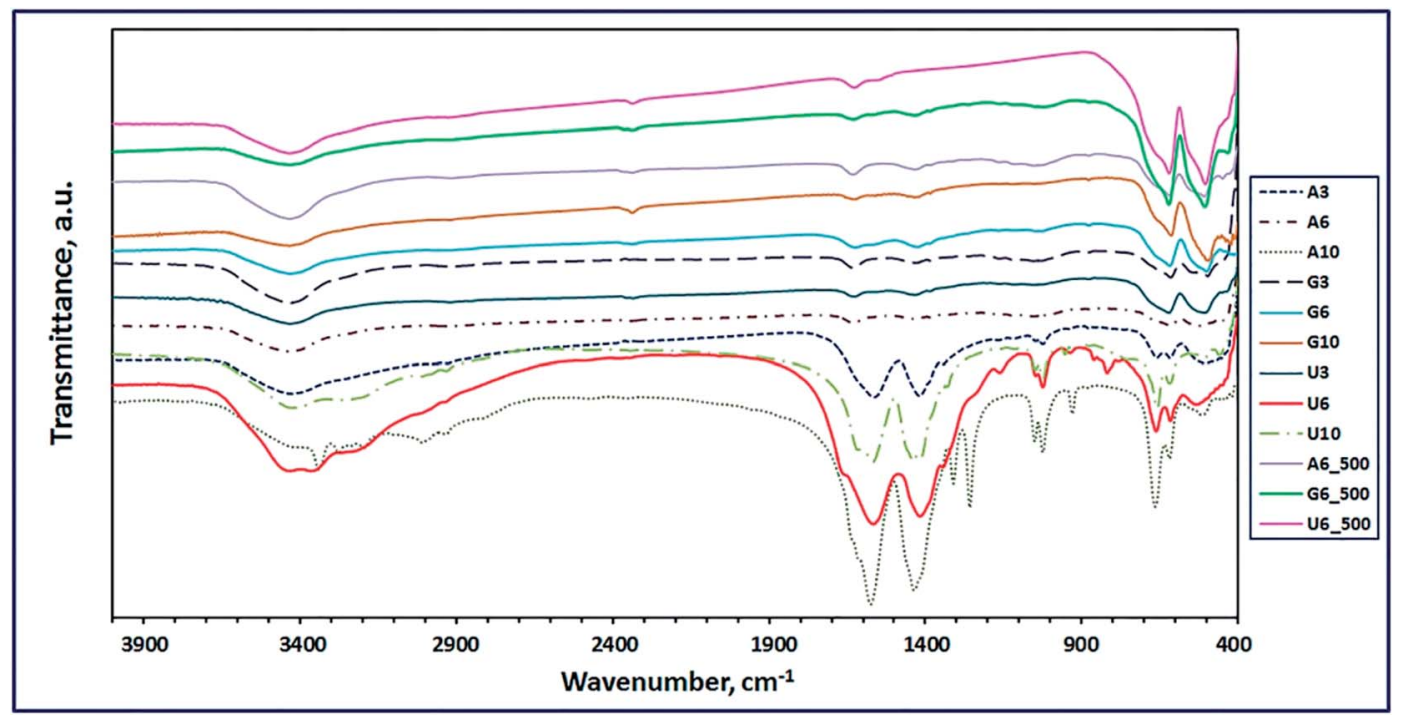

Fig. 4 FT-IR spectra of the as-fabricated $\mathrm{ZnMn}_{2} \mathrm{O}_{4}$ products after combustion and calcination ( $\mathrm{A}_{6 \_500}, \mathrm{G}_{6 \_500}$, and $\mathrm{U}_{6 \_500}$ ) using L-alanine, glycine and urea fuels, respectively.

Table 2 FT-IR vibrational frequencies of the as-synthesized products

\begin{tabular}{|c|c|c|c|c|c|c|c|c|c|}
\hline Product & Label & $\nu_{\mathrm{Mn}-\mathrm{O}}, \mathrm{cm}^{-1}$ & $\nu_{\mathrm{Zn}-\mathrm{O}}, \mathrm{cm}^{-1}$ & $\nu_{\mathrm{MnCO}_{3}}, \mathrm{~cm}^{-1}$ & $\nu_{\mathrm{ZnCO}_{3}}, \mathrm{~cm}^{-1}$ & $\nu_{\mathrm{C}-\mathrm{O}}, \mathrm{cm}^{-1}$ & $\nu_{\mathrm{CH}_{2}}, \mathrm{~cm}^{-1}$ & $\nu_{\mathrm{OH}}, \mathrm{cm}^{-1}$ & $\delta_{\mathrm{OH}}, \mathrm{cm}^{-1}$ \\
\hline $\mathrm{ZnMn}_{2} \mathrm{O}_{4}$ & $\mathrm{~A}_{3}$ & 600,617 & 510 & - & - & 1024 & 1419 & 3430 & 1563 \\
\hline $\mathrm{ZnO}$ & & - & 510 & - & - & & & & \\
\hline $\mathrm{MnO}$ & & 600 & - & - & - & & & & \\
\hline $\mathrm{ZnMnO}_{3}$ & $\mathrm{~A}_{6}$ & 617 & $500^{\mathrm{sh} a}$ & - & - & 1054 & 1432 & 3433 & 1613 \\
\hline $\mathrm{ZnO}$ & & - & $500^{\mathrm{sh} a}$ & - & - & & & & \\
\hline $\mathrm{Mn}_{3} \mathrm{O}_{4}$ & & 520,617 & - & - & - & & & & \\
\hline $\mathrm{Zn}(\mathrm{OH})\left(\mathrm{NO}_{3}\right)\left(\mathrm{H}_{2} \mathrm{O}\right)$ & $\mathrm{A}_{10}$ & - & 463 & - & - & 1024 & 1436 & 3339 & 1575 \\
\hline $\begin{array}{l}\left(\mathrm{Mn}_{2} \mathrm{Zn}\right)_{7}(\mathrm{OH})_{10} \\
\left(\mathrm{CO}_{3}\right)_{2} \mathrm{Zn}_{5}(\mathrm{OH})_{8}\end{array}$ & & 522,665 & 463 & $\begin{array}{l}1253,105, \\
930,665,463\end{array}$ & $\begin{array}{l}1253,1050, \\
930,665,463\end{array}$ & & & & \\
\hline $\mathrm{ZnMn}_{2} \mathrm{O}_{4}$ & $\mathrm{G}_{3}$ & 615 & 496 & - & - & 1052 & 1431 & 3432 & 1631 \\
\hline $\mathrm{ZnMn}_{2} \mathrm{O}_{4}$ & $\mathrm{G}_{6}$ & 618 & 501 & - & - & $1050^{\mathrm{sh} a}$ & 1426 & 3432 & 1623 \\
\hline $\mathrm{ZnMn}_{2} \mathrm{O}_{4}$ & $\mathrm{G}_{10}$ & 613 & 494 & - & - & - & 1436 & 3434 & 1626 \\
\hline $\mathrm{ZnO}$ & & - & 458 & - & - & & & & \\
\hline $\mathrm{Mn}_{3} \mathrm{O}_{4}$ & & 613,494 & - & - & - & & & & \\
\hline $\mathrm{Mn}_{5} \mathrm{O}_{8}$ & & 877,613 & - & - & - & & & & \\
\hline $\mathrm{Mn}_{3} \mathrm{O}_{4}$ & $\mathrm{U}_{3}$ & 508,621 & 508 & - & - & 1053 & 1433 & 3433 & 1626 \\
\hline $\mathrm{ZnMn}_{2} \mathrm{O}_{4}$ & & 508,621 & & - & - & & & & \\
\hline $\mathrm{Mn}_{3} \mathrm{O}_{4}$ & $\mathrm{U}_{6}$ & 534,616 & 534 & - & - & 1024 & 1417 & 3432 & 1566 \\
\hline $\mathrm{ZnMnO}_{3}$ & & 534,616 & & - & - & & & & \\
\hline $\begin{array}{l}\left(\mathrm{Mn}_{2} \mathrm{Zn}\right)_{7}(\mathrm{OH})_{10} \\
\left(\mathrm{CO}_{3}\right)_{2}\end{array}$ & $\mathrm{U}_{10}$ & 658 & 460 & $1416,952,658$ & $1416,952,460$ & 1049 & 1440 & 3427 & 1567 \\
\hline $\mathrm{ZnMn}_{2} \mathrm{O}_{4}$ & $\mathrm{~A}_{6 \_500}$ & 620 & 508 & - & - & 1052 & 1431 & 3434 & 1631 \\
\hline $\mathrm{ZnMn}_{2} \mathrm{O}_{4}$ & $\mathrm{G}_{6 \_500}$ & 621 & 505 & - & - & - & - & 3434 & 1632 \\
\hline $\mathrm{ZnMn}_{2} \mathrm{O}_{4}$ & $\mathrm{U}_{6 \_500}^{-}$ & 620 & 504 & - & - & - & - & 3434 & 1626 \\
\hline
\end{tabular}

for $2 \mathrm{~h}$ to eliminate the organic residues and converting some multi-phases products into single-phase products. The FT-IR spectra of the calcined products $\left(\mathrm{A}_{6 \_500}, \mathrm{G}_{6 \_500}, \mathrm{U}_{6 \_500}\right)$ are depicted in Fig. 4. Interestingly, the calcined products; $\mathrm{G}_{6 \_500}$ and $\mathrm{U}_{6 \_500}$, of the combustion samples generated from glycine and urea fuels, respectively, are composed of pure $\mathrm{ZnMn}_{2} \mathrm{O}_{4}$ phase. This was clear by the presence of only the characteristic vibrational frequencies of $\mathrm{ZnMn}_{2} \mathrm{O}_{4}$ product (ca. 508 and
$620 \mathrm{~cm}^{-1}$ ). However, calcination of the combustion products generated using alanine fuel did not produce pure product, and it generated organic residue along with $\mathrm{ZnMn}_{2} \mathrm{O}_{4}$ product $\left(\mathrm{A}_{6 \_500}\right)$, as listed in Table 2. Fig. 4 also shows two characteristic vibrational absorptions corresponding to bending and stretching vibrations of $\mathrm{OH}$ groups of adsorbed water on all products at ca. 1600 and $3430 \mathrm{~cm}^{-1}$, respectively. These results are 

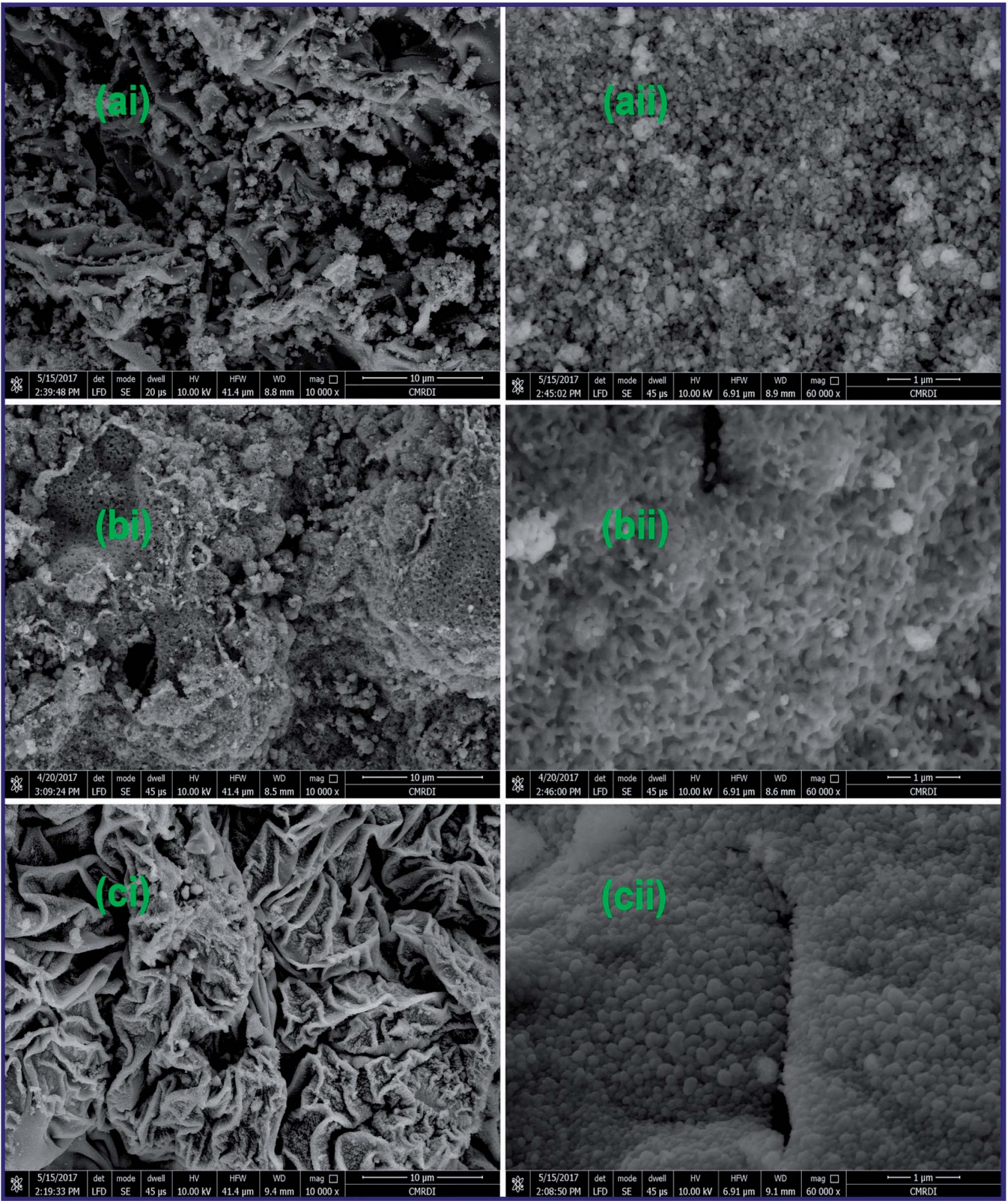

Fig. 5 FE-SEM images of the as-fabricated $\mathrm{ZnMn}_{2} \mathrm{O}_{4}$ products after calcination $\left(\mathrm{A}_{6 \_500}\right.$ (a), $\mathrm{G}_{6 \_500}(\mathrm{~b})$, and $\left.\mathrm{U}_{6 \_500}(\mathrm{c})\right)$ by $\mathrm{L}-\mathrm{alanine}$, glycine and urea fuels, respectively.

consistent with the reported data. ${ }^{\mathbf{6}, 20,50-54}$ The vibrational frequencies of the produced products are presented in Table 2 .

3.1.3. Morphology investigation. The morphology of the asfabricated $\mathrm{ZnMn}_{2} \mathrm{O}_{4}$ products: $\mathrm{A}_{6-500}, \mathrm{G}_{6-500}$, and $\mathrm{U}_{6-500}$, calcined at $500{ }^{\circ} \mathrm{C}$ was investigated by using a field-emission scanning electron microscope (FE-SEM). As shown in Fig. 5(ai), L-alanine fuel generated $\mathrm{ZnMn}_{2} \mathrm{O}_{4}$ nanostructure $\left(A_{6 \_500}\right)$ with aggregates in the form of irregular and curled 
layers. However, a high-magnification FE-SEM image (Fig. 5(aii)) exhibits that those layers are composed of sphere-like particles with an average diameter of $c a .80 \mathrm{~nm}$. Fig. 5(aii) also shows the existence of in-plane pores within the $\mathrm{ZnMn}_{2} \mathrm{O}_{4}$

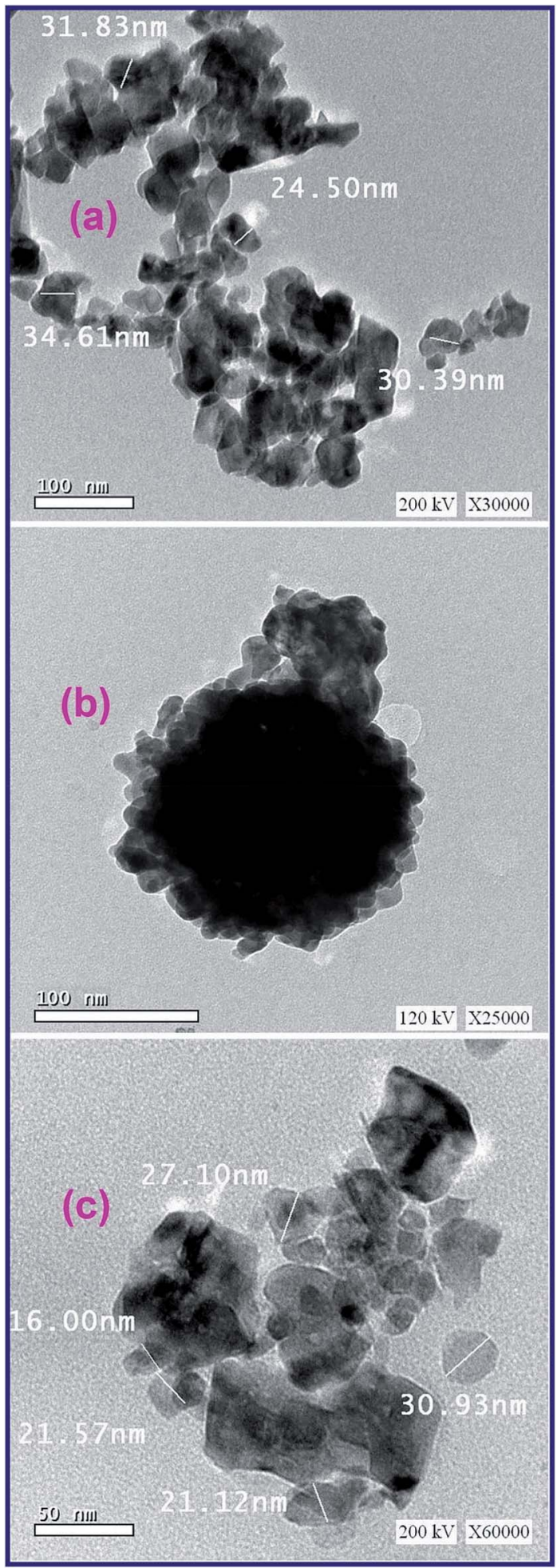

Fig. 6 TEM images of the as-fabricated $\mathrm{ZnMn}_{2} \mathrm{O}_{4}$ products after calcination $\left(A_{6} 500(a), G_{6} 500(b)\right.$, and $U_{6} 500$ (c)) generated by Lalanine, glycine and urea fuels, respectively. layers. However, there are some dark spots appeared in those FE-SEM images (Fig. 5(ai and ii)) indicating the presence of some carbon residues along with the $\mathrm{ZnMn}_{2} \mathrm{O}_{4}$ product. Fig. 5(bi) revealed that glycine fuel produced $\mathrm{ZnMn}_{2} \mathrm{O}_{4}$ product $\left(\mathrm{G}_{6 \_500}\right)$ with porous irregular agglomerates composed of porous peanut-like particles with an average size of $c a .300 \mathrm{~nm}$, as shown in a high-magnification FE-SEM image (Fig. 5(bii)). Whereas, the calcined $\mathrm{ZnMn}_{2} \mathrm{O}_{4}$ product particles ( $\mathrm{U}_{6 \_500}$ ), produced from combustion with urea fuel, were aggregated in thick curled layers and these layers were agglomerated in flower-like structures as shown in a low-magnification FE-SEM image (Fig. 5(ci)). Close inspection of the high-magnification FE-SEM image (Fig. 5(cii)) of these layers, revealed that the layers consisted of uniform sphere-like particles with an average diameter of $c a .100 \mathrm{~nm}$. Notably, the porous structures of the $\mathrm{ZnMn}_{2} \mathrm{O}_{4}$ products are produced during the combustion process by action of the released gases (e.g. $\mathrm{CO}_{2}$ and $\mathrm{N}_{2}$ ) at elevated temperatures. ${ }^{20,21,53}$ The detailed structures of the $\mathrm{ZnMn}_{2} \mathrm{O}_{4}$ products calcined at $500{ }^{\circ} \mathrm{C}$ are displayed in TEM images (Fig. 6). Fig. $6(\mathrm{a}-\mathrm{c})$ showed that the products generated by the three different fuels have similar morphologies. And the produced $\mathrm{ZnMn}_{2} \mathrm{O}_{4}$ particles have a hexagon, sphere, and cubelike structures with an average particle size of $c a$. 30, 20, 25, for
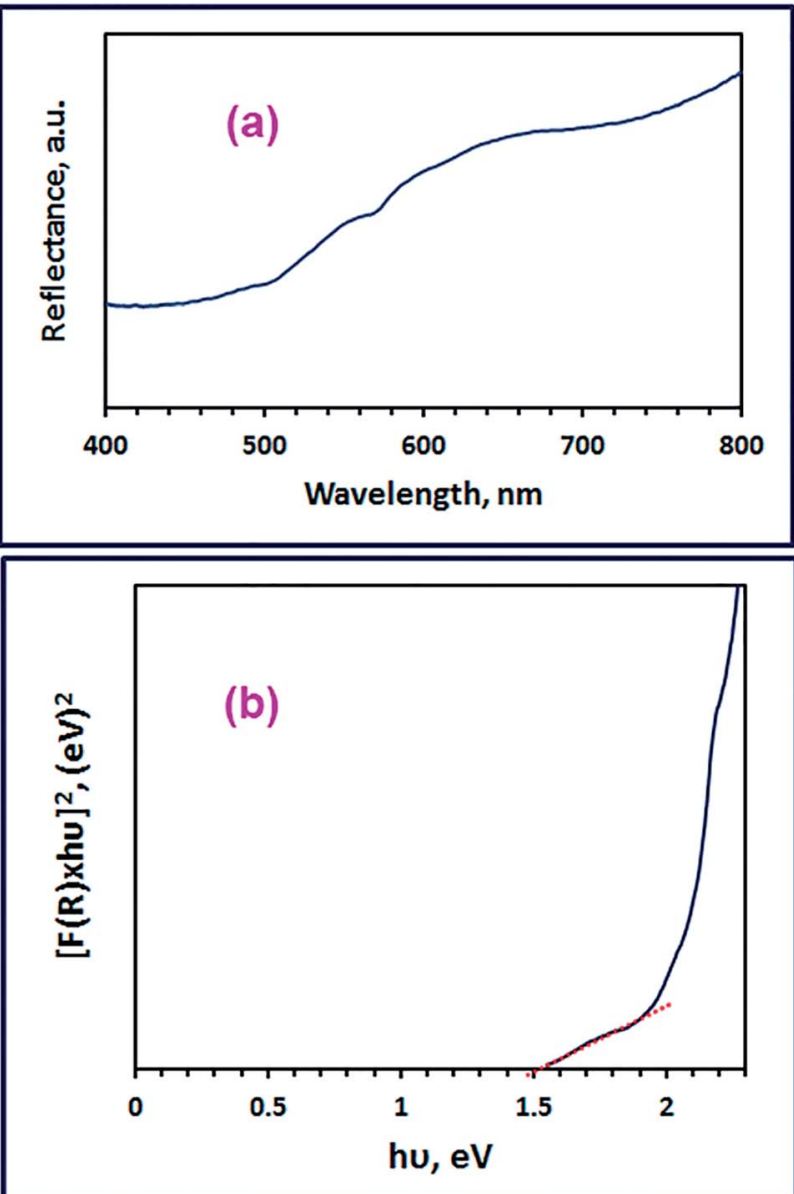

Fig. 7 Diffuse reflectance spectrum (a), and plot $[F(R) x h \nu]^{2}$ against $h \nu$ (b) of the as-fabricated $\mathrm{ZnMn}_{2} \mathrm{O}_{4}$ product $\left(\mathrm{G}_{6} 500\right)$. 
$\mathrm{A}_{6 \_500}, \mathrm{G}_{6 \_500}$, and $\mathrm{U}_{6 \_500} \mathrm{ZnMn}_{2} \mathrm{O}_{4}$ products, respectively. The obtained results are compatible with the XRD ones. Eventually, the EDS analysis results (not shown here) support that the assynthesized spinel $\mathrm{ZnMn}_{2} \mathrm{O}_{4}$ is composed solely of zinc, manganese, and oxygen elements.

3.1.4. Optical properties investigation. We focused in our subsequent investigation on the spinel $\mathrm{ZnMn}_{2} \mathrm{O}_{4}$ product $\left(\mathrm{G}_{6 \_500}\right)$ fabricated using glycine fuel owing to its small crystallite size and high purity compared to the other products $\left(\mathrm{A}_{6 \_500}\right.$ and $\left.\mathrm{U}_{6 \_500}\right)$. The optical band gap energy $\left(E_{\mathrm{g}}\right)$ of the spinel $\mathrm{ZnMn}_{2} \mathrm{O}_{4}$ product $\left(\mathrm{G}_{6 \_500}\right)$ can be determined employing its UVVis diffuse reflectance spectrum (Fig. 7(a)) by utilizing the Kubelka-Munk function, $F(R)$, (eqn (5)). ${ }^{55,56}$

$$
F(R)=\frac{(1-R)^{2}}{2 R}
$$

where, $R$ corresponds to the percentage reflectance. Fig. 7(a) reveals an absorption band in the visible region at $c a .656 \mathrm{~nm}$ which is consistent with the published results. ${ }^{10}$ The spinel $\mathrm{ZnMn}_{2} \mathrm{O}_{4}$ product $\left(\mathrm{G}_{6 \_500}\right)$ direct band gap energy was calculated by plotting $[F(R) x h \nu]^{2}$ versus $h \nu$ (Fig. $7(\mathrm{~b})$ ) where $h \nu$ is the incident photon energy (eV). Then, the band gap energy value $\left(E_{\mathrm{g}}\right)$ of the as-fabricated spinel $\mathrm{ZnMn}_{2} \mathrm{O}_{4}$ product $\left(\mathrm{G}_{6-500}\right)$ was determined to be $1.51 \mathrm{eV}$, utilizing the extrapolation of the linear section of the plot at $[F(R) x h \nu]^{2}=0$. And the calculated band gap energy value is compatible with the reported ones. ${ }^{\mathbf{1 0 , 1 4}}$ The estimated band gap energy value indicates the semiconducting properties of the as-fabricated spinel $\mathrm{ZnMn}_{2} \mathrm{O}_{4}$ product $\left(\mathrm{G}_{6 \_500}\right){ }^{2,8}$

\subsection{Colorimetric determination of omeprazole and lansoprazole drugs}

It was reported that organic sulfide compounds can be oxidized to sulfoxide $\left(\mathrm{R}_{2} \mathrm{SO}\right)$ and/or sulfone compounds $\left(\mathrm{R}_{2} \mathrm{SO}_{2}\right)$, or it can even be brominated utilizing $N$-bromosuccinimide. ${ }^{36,57,58}$ The oxidation of drugs containing sulfide groups can be also performed using iodate in an acidic medium and by following the liberated iodine spectrophotometrically, the concentration of the drugs can be determined. ${ }^{\mathbf{5 9 6 0}}$ However, these methods are multistep and tedious procedures. Consequently, we have developed a simple and accurate method for determination of such type of drugs based on their oxidation using semiconducting nanomaterials. This determination method was based on that when the drug containing sulfide functional group was stirred with the as-prepared $\mathrm{ZnMn}_{2} \mathrm{O}_{4}$ nanoparticles, the color of the solution was turned into yellow. In order to be able to interpret this result, we repeated these experiments in

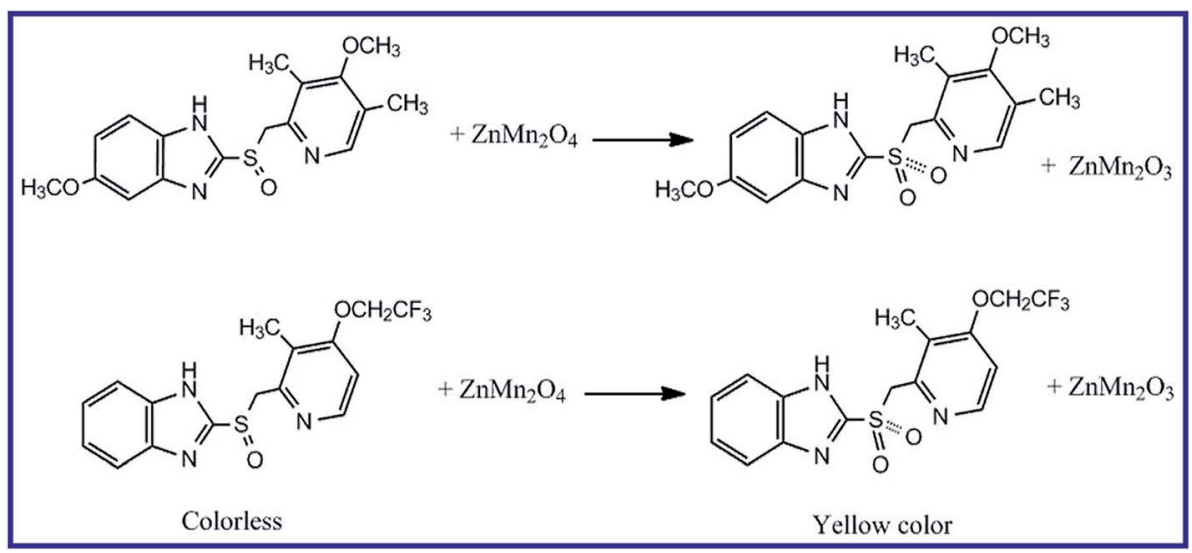

Scheme 3 Proposed mechanism for the oxidation of omeprazole and lansoprazole drugs with $\mathrm{ZnMn}_{2} \mathrm{O}_{4}$ nanoparticles.
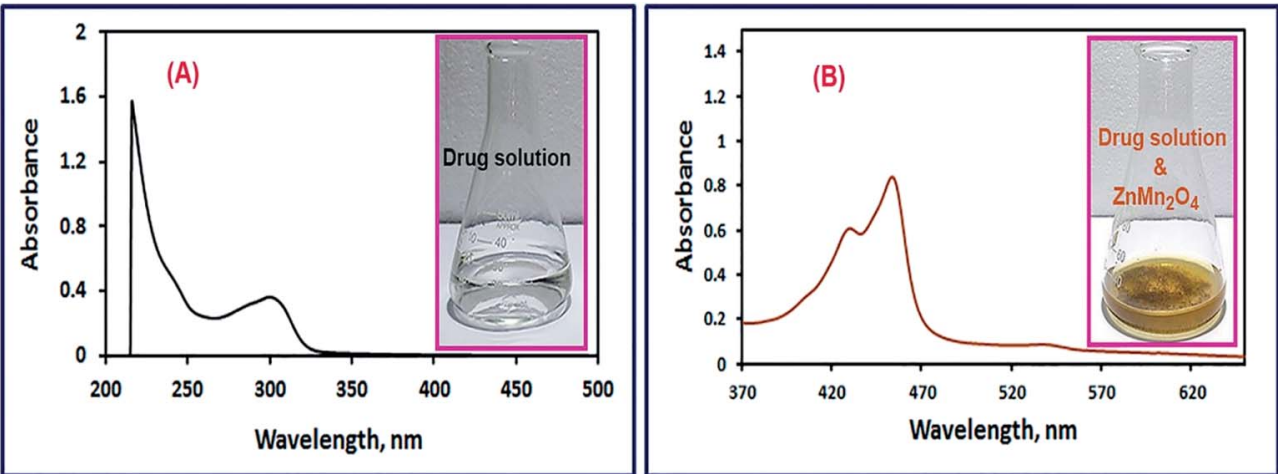

Fig. 8 UV-Vis spectra of omeprazole drug solutions in the absence (A), and presence of $\mathrm{ZnMn}_{2} \mathrm{O}_{4}$ nanoparticles (B). The images of the drug solutions before and after adding $\mathrm{ZnMn}_{2} \mathrm{O}_{4}$ nanoparticles are presented in the inset of the corresponding figures. 

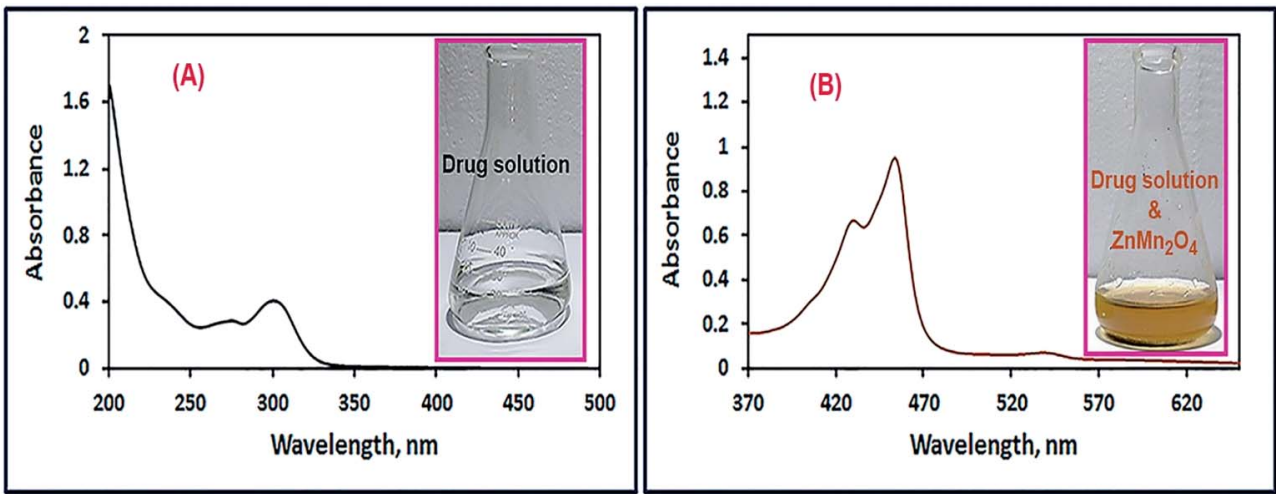

Fig. 9 UV-Vis spectra of lansoprazole drug solutions in the absence (A), and presence of $\mathrm{ZnMn}_{2} \mathrm{O}_{4}$ nanoparticles (B). The images of the drug solutions before and after adding $\mathrm{ZnMn}_{2} \mathrm{O}_{4}$ nanoparticles are presented in the inset of the corresponding figures.

the presence of an oxidizing agent such as $\mathrm{H}_{2} \mathrm{O}_{2}$ and we did not add any amount of $\mathrm{ZnMn}_{2} \mathrm{O}_{4}$ to the reaction. The same yellow color with similar absorbance was obtained. Based on this, we concluded that the produced yellow color upon addition of $\mathrm{ZnMn}_{2} \mathrm{O}_{4}$ to the drugs of interest might be owing to the oxidation of the drugs with that semiconducting material $\left(\mathrm{ZnMn}_{2} \mathrm{O}_{4}\right)$. Moreover, this oxidation may be due to one or two of the following reasons: the first reason is: under visible light, the electrons absorb light and transfer through excitation from valence band to the conduction band of $\mathrm{ZnMn}_{2} \mathrm{O}_{4}$ leaving holes in the valence band. These holes of the valence band may abstract electrons from the sulfide groups of the drugs leading to their oxidation. The second reason is: $\mathrm{Mn}^{3+}$ of the spinel product $\left(\mathrm{ZnMn}_{2} \mathrm{O}_{4}\right)$ may oxidize the drugs, in the presence of $\mathrm{H}_{2} \mathrm{O}$ molecules, from $\mathrm{R}_{2} \mathrm{SO}$ forms to sulfone derivatives $\left(\mathrm{R}_{2} \mathrm{SO}_{2}\right)$, leaving $\mathrm{Mn}^{2+}$. Hence, during the oxidation process of the drugs, some of the spinel $\mathrm{ZnMn}_{2} \mathrm{O}_{4}$ product may be converted into $\mathrm{ZnMn}_{2} \mathrm{O}_{3}$ due to its own reduction, as presented in Scheme 3 . Hence, we have investigated various factors influencing the determination procedure such as selecting absorption wavelength of the oxidized drugs, reaction time, reaction

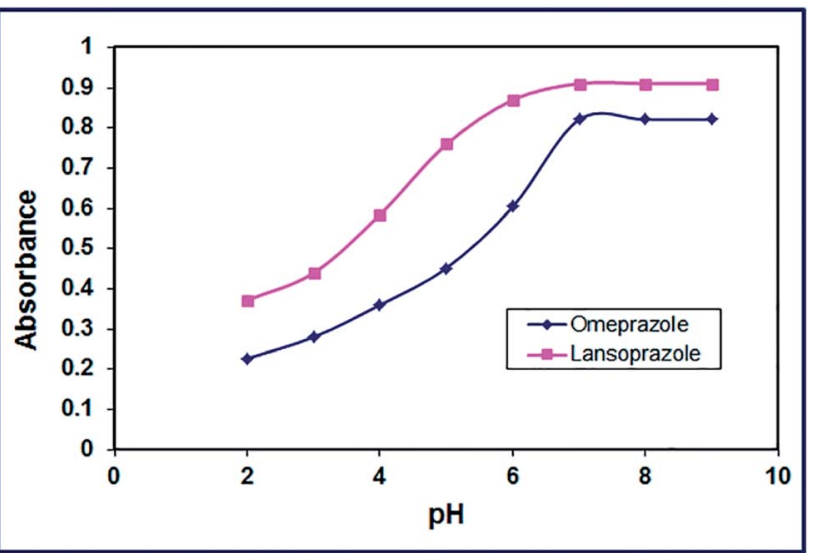

Fig. 10 Effect of $\mathrm{pH}$ of the drug solution on color development of the products. temperature, $\mathrm{pH}$ of the media, volume of the drug solution, concentration of the drugs, and dose of the nanomaterial.

3.2.1. Selection of the appropriate absorption wavelength. A solution of the drug of interest (omeprazole or lansoprazole) was stirred with $50 \mathrm{mg}$ of $\mathrm{ZnMn}_{2} \mathrm{O}_{4}$ nanoparticles, as explained

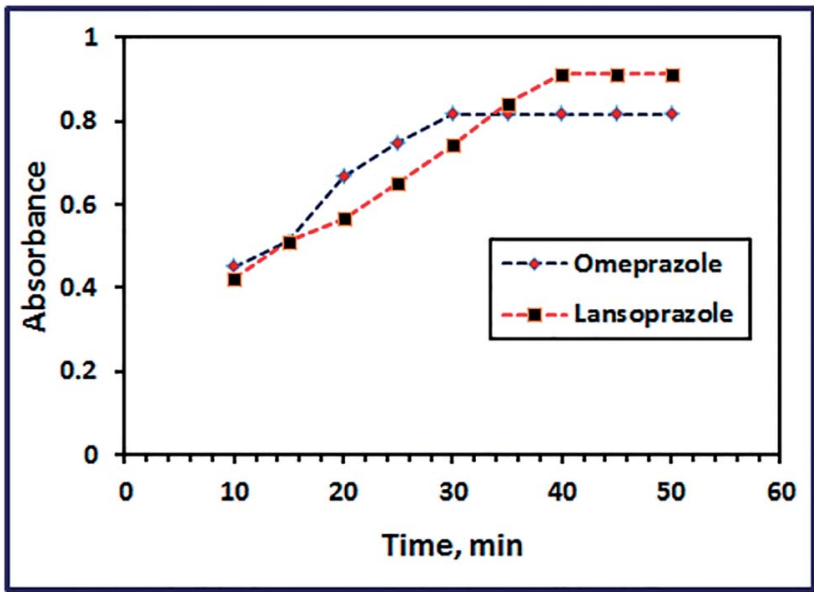

Fig. 11 Effect of reaction time on color development of the products.

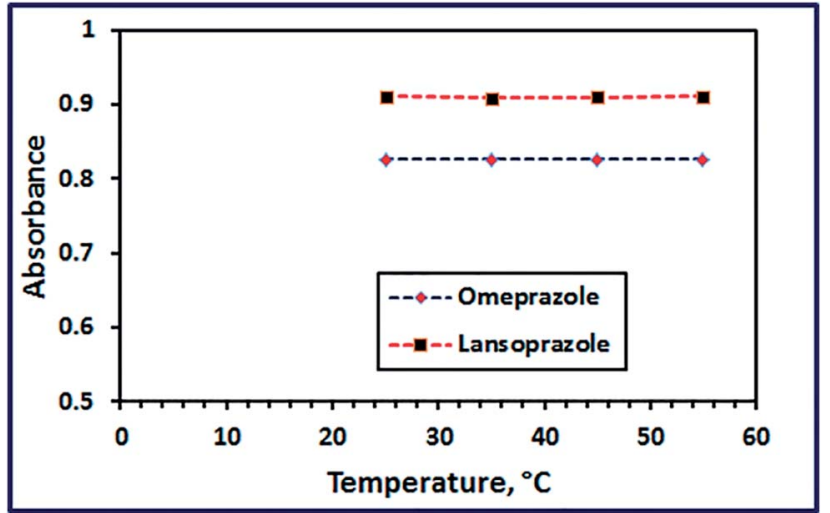

Fig. 12 Effect of reaction temperature on color development of the products. 
in the Experimental section, for $1 \mathrm{~h}$. The produced yellow color was scanned using an UV-Vis spectrophotometer in the wavelength range of $200-800 \mathrm{~nm}$ to detect the $\lambda_{\max }$ of the oxidized

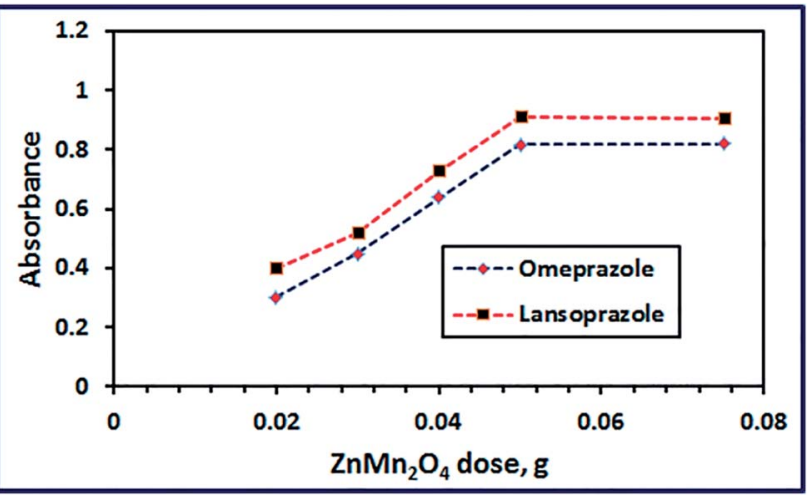

Fig. 13 Effect of $\mathrm{ZnMn}_{2} \mathrm{O}_{4}$ dose on color development of the products.

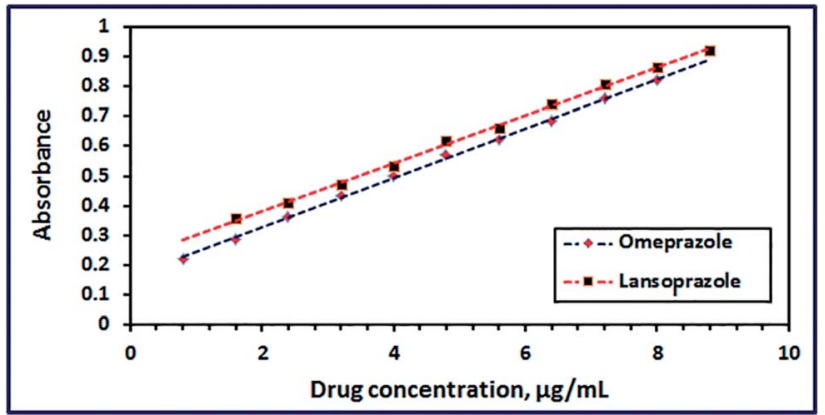

Fig. 14 Calibration plots of omeprazole and lansoprazole drugs using $\mathrm{ZnMn}_{2} \mathrm{O}_{4}$ nanoparticles. drugs. Fig. 8 and 9 exhibited spectra of the omeprazole and lansoprazole drugs, respectively, before and after oxidation with $\mathrm{ZnMn}_{2} \mathrm{O}_{4}$ nanomaterial. The images of the drug solutions before and after adding $\mathrm{ZnMn}_{2} \mathrm{O}_{4}$ nanoparticles are presented in the inset of the corresponding figures (Fig. 8 and 9). The images clearly show turning the colorless color of the drug solutions into yellow color upon addition of the $\mathrm{ZnMn}_{2} \mathrm{O}_{4}$ nanoparticles. The spectra of the oxidized drugs revealed an absorption maximum at ca. $454 \mathrm{~nm}$.

3.2.2. Effect of $\mathbf{p H}$. The influence of reaction media $\mathrm{pH}$ on the color development was examined in the $\mathrm{pH}$ range of 2-9 at ambient temperature $\left(25 \pm 1^{\circ} \mathrm{C}\right)$. The results exhibited that the intensity of the yellow enhanced gradually with increasing the $\mathrm{pH}$ value until it reached its maximum at $\mathrm{pH} 7$ and it remained constant as displayed in Fig. 10. Hence, the optimum $\mathrm{pH}$ value for this color development was opted to be 7 in the subsequent study.

3.2.3. Effect of time. Solutions of the drugs (omeprazole or lansoprazole) were blended with $50 \mathrm{mg}$ of $\mathrm{ZnMn}_{2} \mathrm{O}_{4}$ nanoparticles, as explained in the Experimental section. The optimum reaction time was estimated by following the color development with time elapsed at $\mathrm{pH} 7$ and ambient temperature $\left(25 \pm 1{ }^{\circ} \mathrm{C}\right)$. It is clear from Fig. 11 that complete color intensity of the oxidized drugs was obtained after 30 and $40 \mathrm{~min}$ for omeprazole and lansoprazole drugs, respectively, and the color remained stable for $24 \mathrm{~h}$.

3.2.4. Effect of temperature. Studying the effect of temperature (in the range of $25-55{ }^{\circ} \mathrm{C}$ ) on the color intensity of the oxidized drugs revealed that temperature has not a remarkable effect, as shown in Fig. 12.

3.2.5. Effect of $\mathrm{ZnMn}_{2} \mathrm{O}_{4}$ dose. Effect of $\mathrm{ZnMn}_{2} \mathrm{O}_{4}$ nanostructure dose on the color intensity of the oxidized drugs (at $\lambda_{\max } 454 \mathrm{~nm}$ ) has been examined at constant drug concentration and at $\mathrm{pH}$ 7. The results depicted in Fig. 13 exhibited that

Table 3 Comparison of the performance of the proposed method with those of the published methods for the determination of lansoprazole and omeprazole drugs ${ }^{a}$

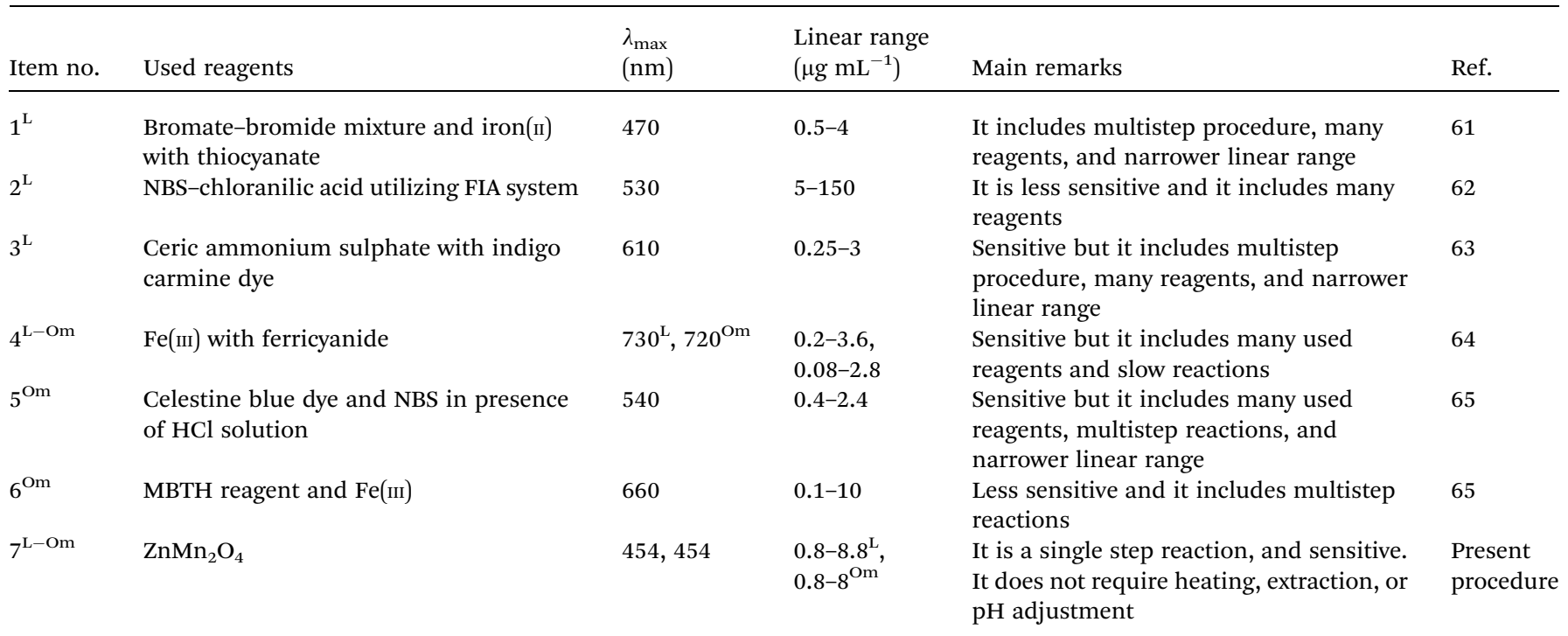

\footnotetext{
${ }^{a}$ Where, $\mathrm{L}=$ lansoprazole, $\mathrm{Om}=$ omeprazole, $\mathrm{MBTH}=3$-methyl-2-benzothiazolinone hydrazine, and NBS $=N$-bromosuccinimide.
} 
the color intensity of the reaction mixture enhanced with increasing the nano-material quantity until it reached maximum at $50 \mathrm{mg}$. Afterward, increasing the $\mathrm{ZnMn}_{2} \mathrm{O}_{4}$ nanosensor dose did not have any significant influence on the color intensity.

3.2.6. Calibration and precision of the $\mathrm{ZnMn}_{2} \mathrm{O}_{4}$ chemical nanosensor. Typical calibration curves for omeprazole and lansoprazole with the as-prepared $\mathrm{ZnMn}_{2} \mathrm{O}_{4}$ nanosensor obtained from linear regression analysis of absorbance against concentration of the drugs $\left(\mu \mathrm{g} \mathrm{mL}^{-1}\right)$ were made. Plotting the concentration of each drug versus its absorbance revealed that Beer's law limits were $0.80-8.0$ and $0.80-8.8 \mu \mathrm{g} \mathrm{mL}{ }^{-1}$ at $\lambda_{\max }$ $454 \mathrm{~nm}$ for omeprazole and lansoprazole, respectively, as shown in Fig. 14. Moreover, the corresponding correlation coefficients are 0.999 and 0.998 for omeprazole and lansoprazole drugs, respectively. The Sandell sensitivity was estimated to be 0.012 and $0.0125 \mu \mathrm{g} \mathrm{cm}{ }^{-2}$, for omeprazole and lansoprazole drugs, respectively. Moreover, the limit of detection was found to be 0.264 and $0.093 \mu \mathrm{g} \mathrm{mL}^{-1}$ for omeprazole and lansoprazole, respectively. And the limit of quantification was determined to be 0.88 and $0.98 \mu \mathrm{g} \mathrm{mL}^{-1}$ for omeprazole and lansoprazole, respectively. Therefore, it can be concluded from the above discussion that $\mathrm{ZnMn}_{2} \mathrm{O}_{4}$ nanostructure can be applied as a chemical nanosensor to detect omeprazole and lansoprazole drugs precisely in ethanolic solutions. On the other hand, some of the published spectrophotometric methods have one or more disadvantages, such as using extraction or heating during determination, low sensitivity, or determination narrow range, as tabulated in Table 3.

\section{Conclusions}

In this investigation, a novel approach has been adopted to use $\mathrm{ZnMn}_{2} \mathrm{O}_{4}$ nanostructure as a chemical nanosensor. Different $\mathrm{ZnMn}_{2} \mathrm{O}_{4}$ nanostructures have been synthesized using different fuels such as L-alanine, glycine, and urea via an autocombustion process. Various factors influencing the combustion process have been explored. Glycine fuel produced the purest spinel $\mathrm{ZnMn}_{2} \mathrm{O}_{4}$ product on combustion while the other fuels generated multi-phases. The as-prepared spinel $\mathrm{ZnMn}_{2} \mathrm{O}_{4}$ nanostructure proved its efficiency as a chemical nanosensor for the sensitive determination of omeprazole and lansoprazole drugs. The developed chemical nanosensor showed high sensitivity, low detection limit, and a relatively wide linear range (0.80-8.0 and $0.80-8.8 \mu \mathrm{g} \mathrm{mL}^{-1}$ at $\lambda_{\max } 454 \mathrm{~nm}$ for omeprazole and lansoprazole, respectively). This study may open a new approach for developing new chemical sensors for colorimetric determination of various drugs.

\section{Conflicts of interest}

There are no conflicts to declare.

\section{References}

1 M. Y. Nassar and M. Khatab, Cobalt ferrite nanoparticles via a template-free hydrothermal route as an efficient nano- adsorbent for potential textile dye removal, $R S C A d v ., 2016$, 6, 79688-79705.

$2 \mathrm{M}$. Y. Nassar and S. Abdallah, Facile controllable hydrothermal route for a porous $\mathrm{CoMn}_{2} \mathrm{O}_{4}$ nanostructure: synthesis, characterization, and textile dye removal from aqueous media, $R S C A d v ., 2016$, 6, 84050-84067.

3 N. Guo, X. Q. Wei, X. L. Deng and X. J. Xu, Synthesis and property of spinel porous $\mathrm{ZnMn}_{2} \mathrm{O}_{4}$ microspheres, Appl. Surf. Sci., 2015, 356, 1127-1134.

4 W. Dang, F. Wang, Y. Ding, C. Feng and Z. Guo, Synthesis and electrochemical properties of $\mathrm{ZnMn}_{2} \mathrm{O}_{4}$ microspheres for lithium-ion battery application, J. Alloys Compd., 2017, 690, 72-79.

5 M. Y. Nassar, T. Y. Mohamed and I. S. Ahmed, One-pot solvothermal synthesis of novel cobalt salicylaldimine-urea complexes: a new approach to $\mathrm{Co}_{3} \mathrm{O}_{4}$ nanoparticles, J. Mol. Struct., 2013, 1050, 81-87.

6 M. Y. Nassar, Size-controlled synthesis of $\mathrm{CoCO}_{3}$ and $\mathrm{Co}_{3} \mathrm{O}_{4}$ nanoparticles by free-surfactant hydrothermal method, Mater. Lett., 2013, 94, 112-115.

7 M. Y. Nassar and I. S. Ahmed, Template-free hydrothermal derived cobalt oxide nanopowders: synthesis, characterization, and removal of organic dyes, Mater. Res. Bull., 2012, 47, 2638-2645.

8 M. Y. Nassar and I. S. Ahmed, Hydrothermal synthesis of cobalt carbonates using different counter ions: an efficient precursor to nano-sized cobalt oxide $\left(\mathrm{Co}_{3} \mathrm{O}_{4}\right)$, Polyhedron, 2011, 30, 2431-2437.

9 J. Yuan, C. Chen, Y. Hao, X. Zhang, R. Agrawal, W. Zhao, C. Wang, H. Yu, X. Zhu, Y. Yu, Z. Xiong and Y. Xie, Fabrication of three-dimensional porous $\mathrm{ZnMn}_{2} \mathrm{O}_{4}$ thin films on $\mathrm{Ni}$ foams through electrostatic spray deposition for high-performance lithium-ion battery anodes, J. Alloys Compd., 2017, 696, 1174-1179.

10 R. Gherbi, Y. Bessekhouad and M. Trari, Structure, optical and transport properties of $\mathrm{Mg}$-doped $\mathrm{ZnMn}_{2} \mathrm{O}_{4}$, J. Alloys Compd., 2016, 655, 188-197.

11 G. Fierro, M. Lo Jacono, M. Inversi, R. Dragone and G. Ferraris, Preparation, characterization and catalytic activity of Co-Zn-based manganites obtained from carbonate precursors, Appl. Catal., B, 2001, 30, 173-185.

12 L. Zhao, X. Li and J. Zhao, Fabrication, characterization and photocatalytic activity of cubic-like $\mathrm{ZnMn}_{2} \mathrm{O}_{4}$, Appl. Surf. Sci., 2013, 268, 274-277.

13 C. Chanel, S. Fritsch, C. Drouet, A. Rousset, M. L. Martínez Sarrión, L. Mestres and M. Morales, Synthesis, thermogravimetric and high temperature X-ray diffraction analyses of zinc-substituted nickel manganites, Mater. Res. Bull., 2000, 35, 431-439.

14 R. Gherbi, Y. Bessekhouad and M. Trari, Optical and transport properties of Sn-doped $\mathrm{ZnMn}_{2} \mathrm{O}_{4}$ prepared by sol-gel method, J. Phys. Chem. Solids, 2016, 89, 69-77.

15 K. Chhor, J. F. Bocquet, C. Pommier and B. Chardon, Heat capacity and thermodynamic behaviour of $\mathrm{Mn}_{3} \mathrm{O}_{4}$ and $\mathrm{ZnMn}_{2} \mathrm{O}_{4}$ at low temperatures, J. Chem. Thermodyn., 1986, 18, 89-99. 
16 K. J. Kim and P. Young Ran, Sol-gel growth and structural and optical investigation of manganese-oxide thin films: structural transformation by Zn doping, J. Cryst. Growth, 2004, 270, 162-167.

17 X.-D. Zhang, Z.-S. Wu, J. Zang, D. Li and Z.-D. Zhang, Hydrothermal synthesis and characterization of nanocrystalline Zn-Mn spinel, J. Phys. Chem. Solids, 2007, 68, 1583-1590.

18 S. Guillemet-Fritsch, C. Chanel, J. Sarrias, S. Bayonne, A. Rousset, X. Alcobe and M. L. Martinez Sarriòn, Structure, thermal stability and electrical properties of zinc manganites, Solid State Ionics, 2000, 128, 233-242.

19 M. Y. Nassar, T. Y. Mohamed, I. S. Ahmed and I. Samir, MgO nanostructure via a sol-gel combustion synthesis method using different fuels: an efficient nano-adsorbent for the removal of some anionic textile dyes, J. Mol. Liq., 2017, 225, 730-740.

20 M. Y. Nassar, E. I. Ali and E. S. Zakaria, Tunable autocombustion preparation of $\mathrm{TiO}_{2}$ nanostructures as efficient adsorbents for the removal of an anionic textile dye, $R S C$ Adv., 2017, 7, 8034-8050.

21 M. Y. Nassar, I. S. Ahmed and I. Samir, A novel synthetic route for magnesium aluminate $\left(\mathrm{MgAl}_{2} \mathrm{O}_{4}\right)$ nanoparticles using sol-gel auto combustion method and their photocatalytic properties, Spectrochim. Acta, Part A, 2014, 131, 329-334.

22 A. Sahoo and Y. Sharma, Synthesis and characterization of nanostructured ternary zinc manganese oxide as novel supercapacitor material, Mater. Chem. Phys., 2015, 149150, 721-727.

23 T. Zhang, Y. Gao, H. Yue, H. Qiu, Z. Guo, Y. Wei, C. Wang, G. Chen and D. Zhang, Convenient and high-yielding strategy for preparing nano- $\mathrm{ZnMn}_{2} \mathrm{O}_{4}$ as anode material in lithium-ion batteries, Electrochim. Acta, 2016, 198, 84-90.

24 N. El-Enany, F. Belal and M. Rizk, The alternating current polarographic behavior and determination of lansoprazole and omeprazole in dosage forms and biological fluids, $J$. Biochem. Biophys. Methods, 2008, 70, 889-896.

25 A. De Milito, R. Canese, M. L. Marino, M. Borghi, M. Iero, A. Villa, G. Venturi, F. Lozupone, E. Iessi, M. Logozzi, P. D. Mina, M. Santinami, M. Rodolfo, F. Podo, L. Rivoltini and S. Fais, pH-dependent antitumor activity of proton pump inhibitors against human melanoma is mediated by inhibition of tumor acidity, Int. J. Cancer, 2010, 127, 207-219.

26 F. C. Souza, T. M. Baptista, E. B. Marques, R. B. M. Barros and C. B. V. Scaramello, Omeprazole does not modulate pharmacokinetic of digoxin in patients with heart failure, Int. J. Cardiol., 2015, 179, 343-344.

27 M. Gabello, M. C. Valenzano, M. Barr, P. Zurbach and J. M. Mullin, Omeprazole Induces Gastric Permeability to Digoxin, Dig. Dis. Sci., 2010, 55, 1255-1263.

28 M. L. C. Montanari, Q. B. Cass, A. Leitão, A. D. Andricopulo and C. A. Montanari, The role of molecular interaction fields on enantioselective and nonselective separation of chiral sulfoxides, J. Chromatogr. A, 2006, 1121, 64-75.

29 A. Ekpe and T. Jacobsen, Effect of Various Salts on the Stability of Lansoprazole, Omeprazole, and Pantoprazole as
Determined by High-Performance Liquid Chromatography, Drug Dev. Ind. Pharm., 1999, 25, 1057-1065.

30 K. D. Altria, S. M. Bryant and T. A. Hadgett, Validated capillary electrophoresis method for the analysis of a range of acidic drugs and excipients, J. Pharm. Biomed. Anal., 1997, 15, 1091-1101.

31 A. Tivesten, S. Folestad, V. Schönbacher and K. Svensson, Nonaqueous capillary electrophoresis for the analysis of labile pharmaceutical compounds, Chromatographia, 1999, 49, S7-S11.

32 A.-A. M. Wahbi, O. Abdel-Razak, A. A. Gazy, H. Mahgoub and M. S. Moneeb, Spectrophotometric determination of omeprazole, lansoprazole and pantoprazole in pharmaceutical formulations, J. Pharm. Biomed. Anal., 2002, 30, 1133-1142.

33 A. Radi, Anodic voltammetric assay of lansoprazole and omeprazole on a carbon paste electrode, J. Pharm. Biomed. Anal., 2003, 31, 1007-1012.

34 A. M. Qaisi, M. F. Tutunji and L. F. Tutunji, Acid decomposition of omeprazole in the absence of thiol: a differential pulse polarographic study at the static mercury drop electrode (SMDE), J. Pharm. Sci., 2006, 95, 384-391.

35 A. Ghaemi, S. Rayati, S. Zakavi and N. Safari, Highly efficient oxidation of sulfides to sulfones with tetra-nbutylammonium hydrogen monopersulfate catalyzed by $\beta$ tri- and tetra-brominated mesotetraphenylporphyrinatomanganese(III) acetate, Appl. Catal., A, 2009, 353, 154-159.

36 K. Kaczorowska, Z. Kolarska, K. Mitka and P. Kowalski, Oxidation of sulfides to sulfoxides. Part 2: oxidation by hydrogen peroxide, Tetrahedron, 2005, 61, 8315-8327.

37 S. R. Jain, K. C. Adiga and V. R. Pai Verneker, A new approach to thermochemical calculations of condensed fuel-oxidizer mixtures, Combust. Flame, 1981, 40, 71-79.

38 M. Radpour, S. Alamolhoda and S. M. Masoudpanah, Effects of $\mathrm{pH}$ value on the microstructure and magnetic properties of solution combusted $\mathrm{Fe}_{3} \mathrm{O}_{4}$ powders, Ceram. Int., 2017, 43, 13729-13734.

39 B. Pourgolmohammad, S. M. Masoudpanah and M. R. Aboutalebi, Effect of starting solution acidity on the characteristics of $\mathrm{CoFe}_{2} \mathrm{O}_{4}$ powders prepared by solution combustion synthesis, J. Magn. Magn. Mater., 2017, 424, 352-358.

40 A. Shanmugavani, R. K. Selvan, S. Layek, L. Vasylechko and C. Sanjeeviraja, Influence of $\mathrm{pH}$ and fuels on the combustion synthesis, structural, morphological, electrical and magnetic properties of $\mathrm{CoFe}_{2} \mathrm{O}_{4}$ nanoparticles, Mater. Res. Bull., 2015, 71, 122-132.

41 T. Peng, X. Liu, K. Dai, J. Xiao and H. Song, Effect of acidity on the glycine-nitrate combustion synthesis of nanocrystalline alumina powder, Mater. Res. Bull., 2006, 41, 1638-1645.

42 R. Jenkins and R. L. Snyder, Introduction to X-ray powder diffractometry, John Wiley \& Sons, Inc., New York, 1996.

43 P. F. Teh, Y. Sharma, Y. W. Ko, S. S. Pramana and M. Srinivasan, Tuning the morphology of $\mathrm{ZnMn}_{2} \mathrm{O}_{4}$ 
lithium ion battery anodes by electrospinning and its effect on electrochemical performance, $R S C A d v$., 2013, 3, 28122821.

44 C. Lan, J. Zhao, L. Zhang, C. Wen, Y. Huang and S. Zhao, Selfassembled nanoporous graphene quantum dot- $\mathrm{Mn}_{3} \mathrm{O}_{4}$ nanocomposites for surface-enhanced Raman scattering based identification of cancer cells, RSC Adv., 2017, 7, 18658-18667.

45 B. Yang, Z. Tian, B. Wang, Z. Sun, L. Zhang, Y. Guo, H. Li and S. Yan, Facile synthesis of $\mathrm{Fe}_{3} \mathrm{O}_{4} /$ hierarchical- $\mathrm{Mn}_{3} \mathrm{O}_{4} /$ graphene oxide as a synergistic catalyst for activation of peroxymonosulfate for degradation of organic pollutants, RSC Adv. , 2015, 5, 20674-20683.

46 M. Y. Nassar, A. S. Amin, I. S. Ahmed and S. Abdallah, Sphere-like $\mathrm{Mn}_{2} \mathrm{O}_{3}$ nanoparticles: facile hydrothermal synthesis and adsorption properties, J. Taiwan Inst. Chem. Eng., 2016, 64, 79-88.

47 M. Y. Nassar, M. M. Moustafa and M. M. Taha, Hydrothermal tuning of the morphology and particle size of hydrozincite nanoparticles using different counterions to produce nanosized $\mathrm{ZnO}$ as an efficient adsorbent for textile dye removal, RSC Adv., 2016, 6, 42180-42195.

48 Z. N. Kayani, F. Nazir, S. Riaz and S. Naseem, Structural, optical and magnetic properties of manganese zinc oxide thin films prepared by sol-gel dip coating method, Superlattices Microstruct., 2015, 82, 472-482.

49 J. Zhang, J. Du, H. Wang, J. Wang, Z. Qu and L. Jia, A novel mild route to hausmannite $\mathrm{Mn}_{3} \mathrm{O}_{4}$ nanocubes at room temperature and its catalytic performance, Mater. Lett., 2011, 65, 2565-2567.

50 H. M. Aly, M. E. Moustafa, M. Y. Nassar and E. A. Abdelrahman, Synthesis and characterization of novel $\mathrm{Cu}(\mathrm{II})$ complexes with 3-substituted-4-amino-5-mercapto1,2,4-triazole Schiff bases: a new route to $\mathrm{CuO}$ nanoparticles, J. Mol. Struct., 2015, 1086, 223-231.

51 M. Mostafa, H. M. Saber, A. A. El-Sadek and M. Y. Nassar, Preparation and performance of 99Mo/99mTc chromatographic column generator based on zirconium molybdosilicate, Radiochim. Acta, 2016, 257-265.

52 M. Y. Nassar, A. S. Attia, K. A. Alfallous and M. F. El-Shahat, Synthesis of two novel dinuclear molybdenum(0) complexes of quinoxaline-2,3-dione: new precursors for preparation of $\alpha-\mathrm{MoO}_{3}$ nanoplates, Inorg. Chim. Acta, 2013, 405, 362-367.

53 M. Y. Nassar, A. A. Ali and A. S. Amin, A facile Pechini sol-gel synthesis of $\mathrm{TiO}_{2} / \mathrm{Zn}_{2} \mathrm{TiO}_{2} / \mathrm{ZnO} / \mathrm{C}$ nanocomposite: an efficient catalyst for the photocatalytic degradation of orange G textile dye, RSC Adv., 2017, 7, 30411-30421.
54 M. Y. Nassar and E. A. Abdelrahman, Hydrothermal tuning of the morphology and crystallite size of zeolite nanostructures for simultaneous adsorption and photocatalytic degradation of methylene blue dye, J. Mol. Liq., 2017, 242, 364-374.

55 P. Pascariu, A. Airinei, M. Grigoras, N. Fifere, L. Sacarescu, N. Lupu and L. Stoleriu, Structural, optical and magnetic properties of $\mathrm{Ni}$ doped $\mathrm{SnO}_{2}$ nanoparticles, J. Alloys Compd., 2016, 668, 65-72.

56 C. Sánchez, E. Flores, M. Barawi, J. M. Clamagirand, J. R. Ares and I. J. Ferrer, Marcasite revisited: optical absorption gap at room temperature, Solid State Commun., 2016, 230, 20-24.

57 P. Kowalski, K. Mitka, K. Ossowska and Z. Kolarska, Oxidation of sulfides to sulfoxides. Part 1: oxidation using halogen derivatives, Tetrahedron, 2005, 61, 1933-1953.

58 A. El-Maaboud and I. Mohamed, Utility of diphenylamine and $\mathrm{N}$-bromosuccinimide for colorimetric determination of certain phenothiazine drugs, Talanta, 1997, 44, 1173-1182.

59 E. Chikwana, B. Davis, M. K. Morakinyo and R. H. Simoyi, Oxyhalogen-sulfur chemistry - kinetics and mechanism of oxidation of methionine by aqueous iodine and acidified iodate, Can. J. Chem., 2009, 87, 689-697.

60 F. A. El-Yazbi and S. M. Blaih, Spectrophotometric and titrimetric determination of clindamycin hydrochloride in pharmaceutical preparations, Analyst, 1993, 118, 577-579.

61 K. Basavaiah, V. Ramakrishna, U. R. Anil kumar and B. C. Somashekar, Spectrophotometric determination of lansoprazole in pharmaceuticals using bromate-bromide mixture based on redox and complexation reactions, Ecletica Quim., 2007, 32, 57-64.

62 I. F. Al-Momani and M. H. Rababah, Validation of HPLC and FIA Spectrophotometric Methods for the Determination of Lansoprazole in Pharmaceutical Dosage Forms and Human Plasma, Am. J. Anal. Chem., 2010, 01, 6.

63 K. Basavaiah, V. Ramakrishna and U. Kumar, Use of ceric ammonium sulphate and two dyes, methyl orange and indigo carmine, in the determination of lansoprazole in pharmaceuticals, Acta Pharmaceutica, 2007, 211.

64 A. A. Syed and A. Syeda, Spectrophotometric determination of certain benzimidazole proton pump inhibitors, Indian J. Pharm. Sci., 2008, 70, 507-510.

65 C. S. P. Sastry, P. Y. Naidu and S. S. N. Murty, Spectrophotometric methods for the determination of omeprazole in bulk form and pharmaceutical formulations, Talanta, 1997, 44, 1211-1217. 